\title{
12. CENOZOIC BENTHIC FORAMINIFERAL BIOSTRATIGRAPHY, PALEOBATHYMETRY, PALEOENVIRONMENTS AND PALEOCEANOGRAPHY OF THE NEW HEBRIDES ISLAND ARC AND NORTH D'ENTRECASTEAUX RIDGE AREA ${ }^{1}$
}

\author{
Kazumi Akimoto $^{2}$
}

\begin{abstract}
This paper discusses the paleobathymetric and paleoenvironmental history of the New Hebrides Island Arc and North d'Entrecasteaux Ridge during Cenozoic time based on benthic foraminiferal and sedimentological data. Oligocene and Pliocene to Pleistocene benthic foraminiferal assemblages from Sites 827, 828, 829, and 832 of Ocean Drilling Program (ODP) Leg 134 (Vanuatu) are examined by means of Q-mode factor analysis. The results of this analysis recognize the following bathymetrically significant benthic foraminiferal biofacies: (1) Globocassidulina subglobosa biofacies and Bulimina aculeata-Bolivinita quadrilatera biofacies representing the upper bathyal zone $(600-1500 \mathrm{~m}) ;(2)$ Gavelinopsis praegeri-Cibicides wuellerstorfi biofacies, indicating the Pacific Intermediate Water (water depth between 1500 and $2400 \mathrm{~m}$ ); (3) Tosaia hanzawai-Globocassidulina muloccensis biofacies, Valvulineria gunjii biofacies, and the Melonis barleeanus-Melonis sphaeroides biofacies, which characterize the lower bathyal zone; (4) the Nuttallides umbonifera biofacies, which characterizes the interval between the lysocline (approximately $3500 \mathrm{~m}$ ) and the carbonate compensation depth (approximately $4500 \mathrm{~m}$ ); and (5) the Rhabdammina abyssorum biofacies representing the abyssal zone below the carbonate compensation depth.

Benthic foraminiferal patterns are used to construct paleobathymetric and paleogeographic profiles of the New Hebrides Island Arc and North d'Entrecasteaux Ridge for the following age boundaries: late Miocene/Pliocene, early/late Pliocene, Pliocene/Pleistocene, and Pleistocene/Holocene.
\end{abstract}

\section{INTRODUCTION}

The New Hebrides Island Arc is located in the western part of the equatorial Pacific Ocean and marks the boundary between the AustraliaIndia Plate and the North Fiji Basin. Two hypotheses have been proposed to account for the origin of this island arc, including (1) a reversal in subduction polarity sometime between 8 and $6 \mathrm{Ma}$ (Chase, 1971), and (2) a continuous eastward subduction zone throughout the Neogene (Luyendyk et al., 1974). Alternatively, the reconstructions of the New Hebrides Island Arc proper mainly are based on biostratigraphic, lithostratigraphic, and sedimentologic data obtained from Cenozoic sequences distributed on Espiritu Santo, Malakula, Maewo, and Pentecost islands in the central part of New Hebrides Island Arc (e.g., Macfarlane et al., 1988).

During the Ocean Drilling Program (ODP) Leg 134, drilling at seven sites (Sites 827-832) penetrated Cenozoic sediments in the New Hebrides Island Arc and on the d'Entrecasteaux Zone (DEZ) to investigate the process of ridge-arc collision and to refine the geologic history of the arc. Drilling sites are situated in two major areas including the d'Entrecasteaux-New Hebrides Island Arc collision zone and the intra-arc North Aoba Basin. Specific sites used for this study consist of Site 828 on the North d'Entrecasteaux Ridge (NDR), Sites 827 and 829 on the accretional prism off Espiritu Santo Island of the Western Belt of the New Hebrides Island Arc, and Site 832 located in the central part of the North Aoba Basin (Fig. 1 and Table 1). This study uses quantitative analysis of benthic foraminiferal biofacies at these sites to delineate Neogene faunal change in the Vanuatu region and as a basis for reconstructing the paleobathymetric history of the New Hebrides Island Arc.

\footnotetext{
${ }^{1}$ Greene, H.G., Collot, J.-Y., Stokking, L.B., et al., 1994. Proc. ODP, Sci. Results, 134: College Station, TX (Ocean Drilling Program).

${ }^{2}$ Nagoya Jiyu Gakuin Junior College, Furui 281, Kumanosho, Shikatsu-cho, Nishikasugai-gun, Aichi Prefecture, 481, Japan.
}

\section{LITHOSTRATIGRAPHY AND AGE}

The Leg 134 Shipboard Scientific Party (Collot, Greene, Stokking, et al., 1992a-d) described the lithostratigraphy and ages of Sites $827,828,829$, and 832 as summarized below:

\section{Site 827}

The sediment of Site 827 consists of Pleistocene volcanic silt (Unit I), and upper Pliocene siltstone (Unit II). Basal units consist of calcareous siltstone interbedded with sed-lithic conglomerate and breccia (Unit III), and volcanic sandstone (Unit IV).

\section{Site 828}

The Cenozoic strata of Site 828 are divided into three units: Unit I (Pleistocene silt or siltstone), Unit II (lower Pliocene foraminiferal ooze), and Unit III (Oligocene nannofossil chalk).

\section{Site 829}

The Cenozoic strata penetrated at Site 829 are sheared by many thrust faults, and are composed of 16 lithostratigraphic units (I to XVI) as identified in cores. The lithologic characteristic of each unit is as follows: Units I and III consist of the Pleistocene clayey volcanic silt. Unit II is represented by upper Oligocene to lower Miocene foraminiferal chalk. Units IV and V are deformed siltstone and chalk and chalk-breccia. Unit VI is characterized by middle Oligocene to lower Miocene calcareous chalk. Units VII and XVI consist of Oligocene ig-lithic breccia. Unit VIII is represented by lower Pliocene foraminiferal chalk. Unit IX contains Pleistocene volcanic silty chalk. Units X of middle to upper Oligocene age and XII of lower to upper Oligocene age are characterized by calcareous chalk. Unit XI of upper Pliocene to Pleistocene age is represented by foraminiferal chalk. Unit XIII is composed of Pliocene or lower Pleistocene volcanic sandstone. Unit XIV is mixed sedimentary rock of Oligocene nannofossil chalk and foraminiferal chalk and clay of Pliocene to Pleistocene age. Unit XV consists of Pliocene to Pleistocene sandy volcanic siltstone. 


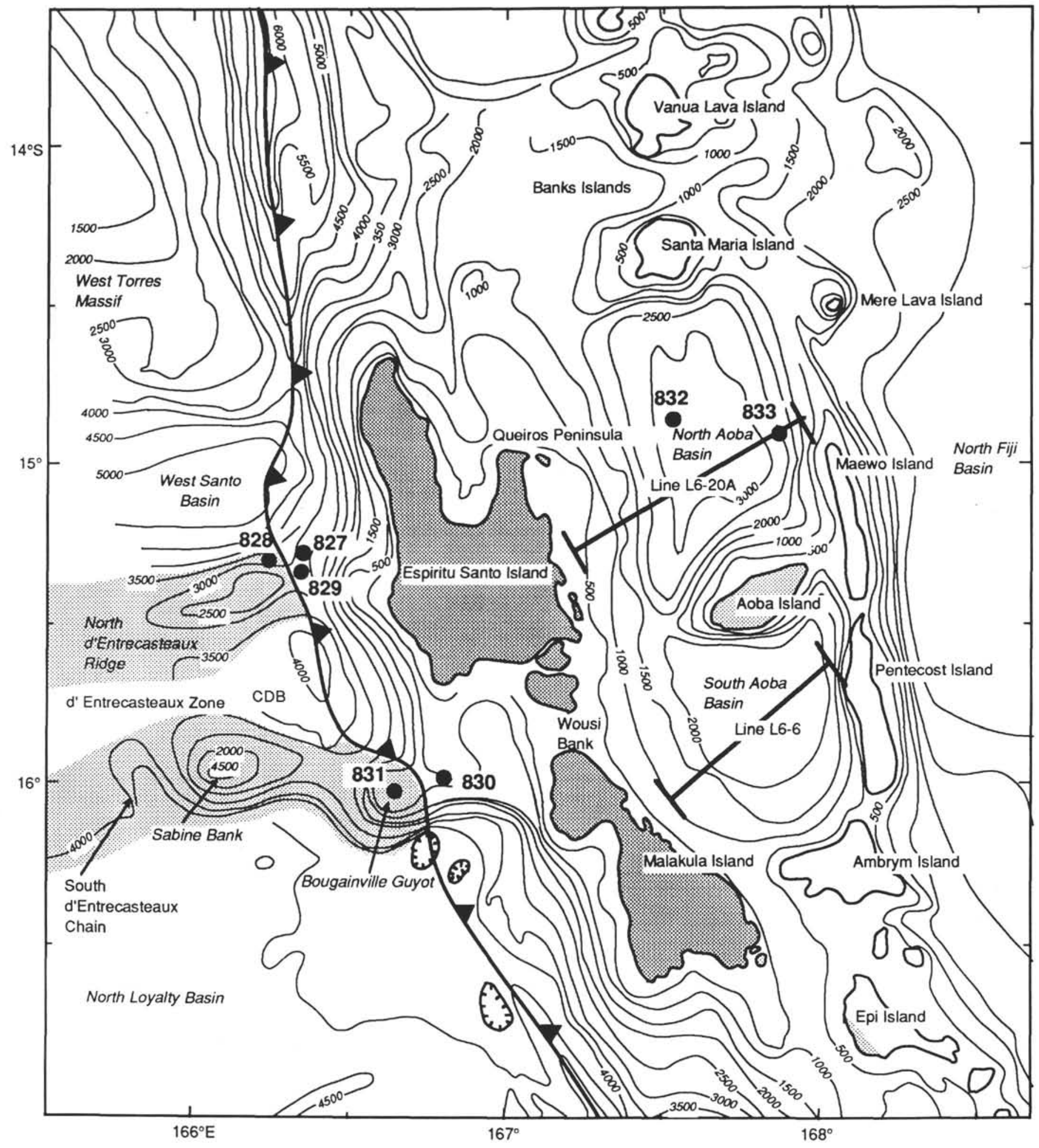

Figure 1. Location of ODP Sites 827-833. Bathymetry in meters.

\section{Site 832}

Neogene strata penetrated at Site 832 are divided into lithostratigraphic Units I to VII. The dominant lithologies in Unit I are Pleistocene sandy to clayey volcanic silts. Unit II consists of Pleistocene sandstone, siltstone, and claystone. The Pleistocene sediments of Unit III are char- acterized by a high abundance of calcareous biogenic materials such as nannofossils and foraminifers. Unit IV consists of upper Pliocene basaltic volcanic sand and breccia. Unit V is predominantly composed of limestone and siltstone of late Miocene to early Pliocene age. Units VI and VII consist of volcanic sandstone and basaltic breccia and volcanic sand of middle to late Miocene age, respectively. 
Table 1. Location of ODP sites discussed.

\begin{tabular}{lllrl}
\hline Site & \multicolumn{1}{c}{ Latitude } & Longitude & Depth $(\mathrm{m})$ & \multicolumn{1}{c}{ Geographic position } \\
\hline 827 & $15^{\circ} 17.741^{\prime} \mathrm{S}$ & $166^{\circ} 21.16^{\prime} \mathrm{E}$ & 2803 & Accretional prism off Espiritu Santo Island \\
828 & $15^{\circ} 17.34^{\prime} \mathrm{S}$ & $166^{\circ} 17.04^{\prime} \mathrm{E}$ & 3087 & North d'Entrecasteaux Ridge \\
829 & $15^{\circ} 18.96^{\prime} \mathrm{S}$ & $166^{\circ} 20.7^{\prime} \mathrm{E}$ & 2905 & Accretional prism off Espiritu Santo Island \\
832 & $15^{\circ} 47.78^{\prime} \mathrm{S}$ & $167^{\circ} 34.35^{\prime} \mathrm{E}$ & 3089 & Northwestern margin of seafloor of North Aoba Basin \\
\hline
\end{tabular}

\section{SEDIMENTOLOGICAL ANALYSIS}

To delineate the origin and nature of the lithostratigraphy at Sites $827,828,829$, and 832 , sediment samples were examined in the laboratory. Prior to choosing foraminifers, each sample was examined for selected biogenic and inorganic grains greater than $0.125 \mathrm{~mm}$ in diameter using a stereomicroscope. The occurrences of coral fragments, pteropods, bivalves, gastropods, echinoid spines, sponge spicules, radiolarians, diatoms, pellets, and plant fragments were counted along with conspicuous inorganic grains of calcite, glauconite, manganese micro-nodules, framboidal pyrite, and chalcopyrite. Figures 2 through 5 show the distribution of these selected materials at each site.

\section{Sites 827 and 829}

Plant fragments occur abundantly in the Holocene and Pleistocene sediment at Sites 827 and 829 , whereas manganese micro-nodules are found only in the calcareous chalk (lithostratigraphic Units XII and XIV) in the basal part of the sequence at Site 829 (Figs. 2 and 3). Mud comprises more than $85 \%$ of most samples at Sites 827 and 829 , but ranges from $45 \%$ to $90 \%$ in Units VII-X (407-436 meters below seafloor [mbsf]) and Units XIII and XIV (463.6-494.77 mbsf) at Site 829. Lower percentages of mud are accompanied by increases in volcanic materials or planktonic foraminiferal tests.

\section{Site 828}

The occurrences of plant fragments are restricted to Pleistocene sediment of Unit I, whereas manganese micronodules are restricted to Oligocene sediments of Unit III (Fig. 4). Mud comprises more than $95 \%$ of the Oligocene sediment of Unit III, about $20 \%$ of the Pliocene sediment of Unit II and from $80 \%$ to $95 \%$ of the Pleistocene strata of Unit I. This value rapidly decreases at the boundary between Units II and III, but gradually increases near the boundary between Units I and II. The samples with less mud are accompanied by abundant planktonic foraminiferal tests (Fig. 4).

\section{Site 832}

Radiolarian tests total more than 1000/g in Holocene strata, but are less abundant ( $>100 / \mathrm{g}$ ) in Pliocene and upper Miocene strata (Fig. 5). Plant fragments occur in both Pleistocene and upper Miocene strata. Samples 134-832B-44R-1, 66-68 cm (lower Pleistocene volcanic clastic sediment), are marked by the occurrence of ferro-manganese oxide grains $(>30 / \mathrm{g})$.

Sediment between 0 and 385.84 mbsf and between 630 and 847 mbsf are characterized by high mud content $(>80 \%)$, whereas mud comprises $20 \%$ to $80 \%$ of sediment between 397 and $630 \mathrm{mbsf}$ and below $847 \mathrm{mbsf}$. Lower mud content is coincident with the occurrence of volcanic sediment in Units II, III, VI, and VII.

The distribution of the various grain types noted above are useful for recognizing paleogeographic and sedimentary environments by comparing with the mud content of Holocene sediment. For example, plant fragments are rare or absent around small islands (Akimoto, 1991). Thus, the occurrences of plant fragments from strata at Sites $827,828,829$, and 832 may imply the existence of a sedimentary basin with a nearby large land area during the late Miocene and Pleistocene. The restricted occurrence of manganese micronodules at
Site 829 suggests that they were reworked from Oligocene deposits on the NDR.

\section{BENTHIC FORAMINIFERAL BIOSTRATIGRAPHY}

\section{Materials and Methods}

Samples analyzed in this study were collected from cores drilled at Sites $827,828,829$, and 832; all four sites are presently located at lower bathyal water depths (Table 1). Each sample analyzed consists of about $15 \mathrm{~cm}^{3}$ of sediment. Unconsolidated sediment samples were washed on a $63-\mu \mathrm{m}$ sieve screen and dried. Rock samples were dried in an oven and then treated with a saturated sodium sulfate solution and naphtha for disintegration (Maiya and Inoue, 1973) and with sodium tetraphenylborate (Yasuda et al., 1985). The samples were then wet-sieved through a $63-\mu \mathrm{m}$ screen and redried.

Benthic foraminiferal specimens are generally rare and moderately to poorly preserved in the samples analyzed. Only samples containing better preserved specimens were quantitatively analyzed. Each sample analyzed was divided by a sample splitter into aliquot parts. In most cases, 100 or more specimens of benthic and planktonic foraminifers larger than $0.125 \mathrm{~mm}$ were picked from an aliquot under a binocular microscope. Finally, 102 samples were selected for benthic foraminiferal analysis based on their stratigraphic location and biohorizons of key species.

\section{General Microfaunal Trends and Microfaunal Analysis}

The distribution of foraminifers in the modern ocean is fundamentally in harmony with the distribution of water masses and patterns of surface water currents (Akimoto, 1990). To reconstruct paleoenvironments, statistical distributions of both fossil and Holocene assemblages were compared. Statistical measures applied include planktonic foraminiferal number, benthic foraminiferal number, the damaged planktonic foraminifers/total planktonic foraminifers (DPF/TPF) ratio, planktonic foraminifers/total foraminifers $(\mathrm{P} / \mathrm{T})$ ratio, and agglutinated foraminifers/total benthic foraminifers $(\mathrm{A} / \mathrm{T})$ ratio. Figure 6 includes a generalized pattern of $\mathrm{P} / \mathrm{T}$ and $\mathrm{A} / \mathrm{T}$ ratios in the modern tropical Pacific Ocean.

Planktonic foraminiferal numbers and benthic foraminiferal numbers represent the number of specimens of planktonic and benthic foraminifers contained in $1 \mathrm{~g}$ of dry sediment. The $\mathrm{P} / \mathrm{T}$ ratio represents the ratio of planktonic foraminifers to total foraminifers (planktonic and benthic foraminifers) in a sample. Lower P/T ratios commonly occur beneath coastal water and in deep-water environments below the foraminiferal lysocline. The A/T ratio represents the ratio of agglutinated foraminifers to total benthic foraminifers (agglutinated and calcareous benthic foraminifers). High values of this ratio may indicate special water mass conditions such as the prevalence of low pH conditions or deposition below the carbonate compensation depth (CCD). The DPF/TPF ratio represents the difference between the number of broken foraminiferal tests to complete tests of planktonic foraminifers. High values of this ratio may reflect abrasion by strong waves or dissolution. Stratigraphic variations in the distribution of the selected sedimentary constituents (e.g., manganese micronodules, plant remains, etc.), as well as general microfaunal parameters, including planktonic and benthic foraminiferal numbers, DPF/TPF, and P/T and A/T ratios for all sites studied are illustrated in Figures 2 through 5. 


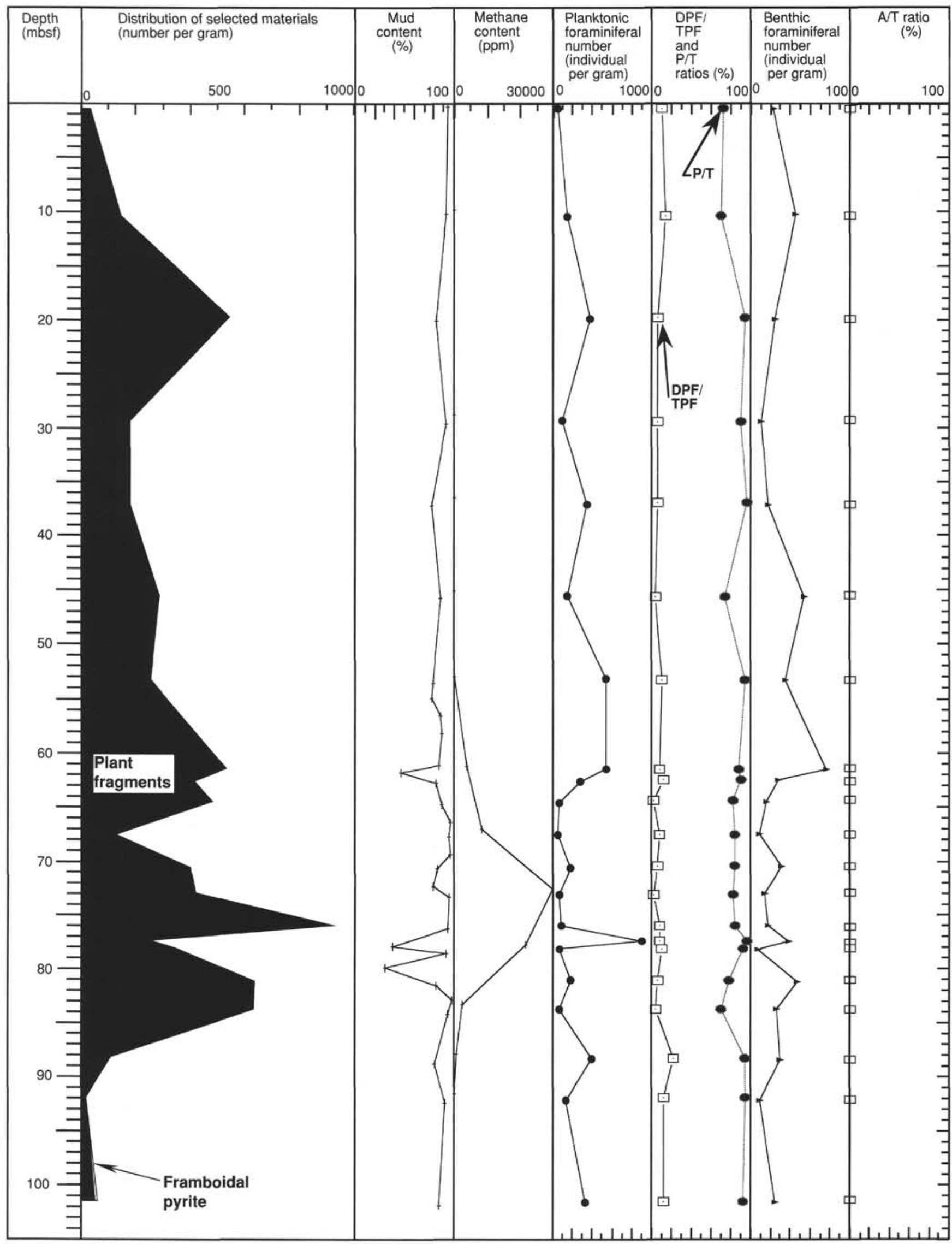

Figure 2. Stratigraphic distribution of selected sedimentary constituents, mud content, planktonic foraminiferal number, benthic foraminiferal number, damaged planktonic foraminifers/total planktonic foraminifers (DPF/TPF) ratio, planktonic foraminifers/total foraminifers (P/T) ratio, and agglutinated foraminifers/total benthic foraminifers $(\mathrm{A} / \mathrm{T})$ ratio at Site 827. 


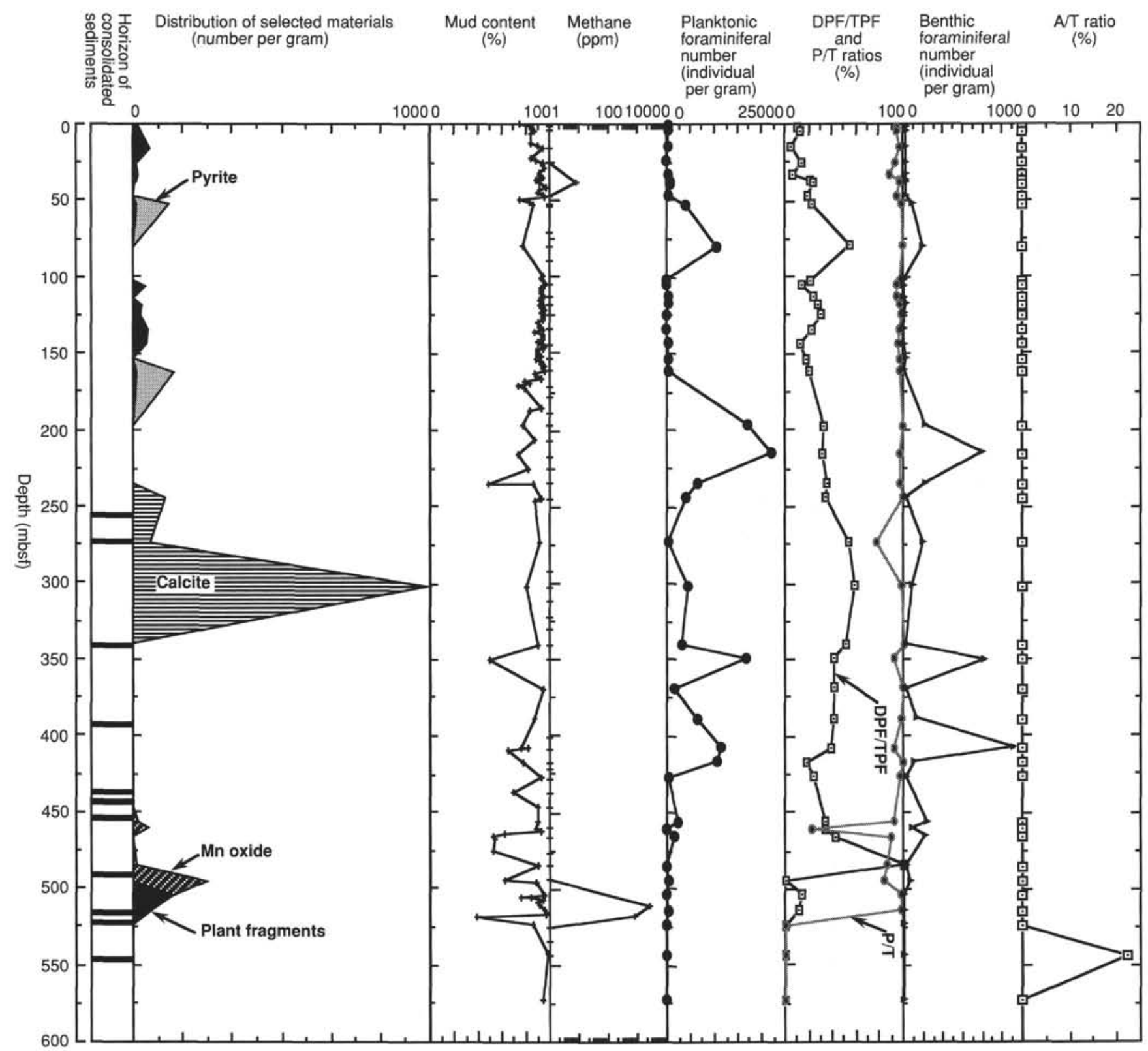

Figure 3. Stratigraphic distribution of selected sedimentary constituents, mud content, planktonic foraminiferal number, benthic foraminiferal number, damaged planktonic foraminifers/total planktonic foraminifers ratio, planktonic foraminifers/total foraminifers ratio, and agglutinated foraminifers/total benthic foraminifers ratio at Site 829.

\section{Bathymetric Zonation and Species Distribution}

Studies of benthic foraminifera in the modern Pacific Ocean have shown that foraminiferal biofacies are well correlated with individual water masses (e.g., Burke, 1981; Hermelim, 1989). Burke (1981) identified specific foraminiferal biofacies associated with the Pacific Intermediate Water (PIW), Pacific Deep Water (PDW), and Pacific Bottom Water (PBW). These latter three water masses occupy depth intervals ranging from 1200 to $2400 \mathrm{~m}$, from 2500 to $3000 \mathrm{~m}$, and from 3000 to $4000 \mathrm{~m}$, respectively.

Several authors have reported relationships between benthic foraminiferal species and physiochemical properties such as dissolved oxygen and substrate type (Burke, 1981; Hermelim, 1989). Older studies have included information on depth distributions of living species and fossil occurrences in the Neogene sequences of the Vanuatu area (Cushman, 1921, 1932, 1933, 1942; Cushman et al., 1954; Todd, 1965).
The following depth classification was used in this study: sublittoral zone $(0-150 \mathrm{~m})$, upper bathyal zone ( $150-500 \mathrm{~m})$, upper middle bathyal zone (500-1500 m), lower middle bathyal zone (1500-2000 $\mathrm{m}$ ), lower bathyal zone (2000-4000 m), and abyssal zone (below 4000 m). Figure 6 shows the relationships between bathymetric zones, water masses, and depth distributions of the major species in the modern equatorial Pacific Ocean region. These Pacific data were used to interpret paleoenvironmental and paleobathymetric change at the sites studied.

\section{Factor Analysis}

Factor analysis (Q-mode) was used to reduce the data into meaningful groups. Factors are patterns reflecting the distribution of variables. A variable, in this case a foraminifer, can have a similarity to a factor (factor loading) ranging from +1.0 to -1.0 . In this analysis, any 


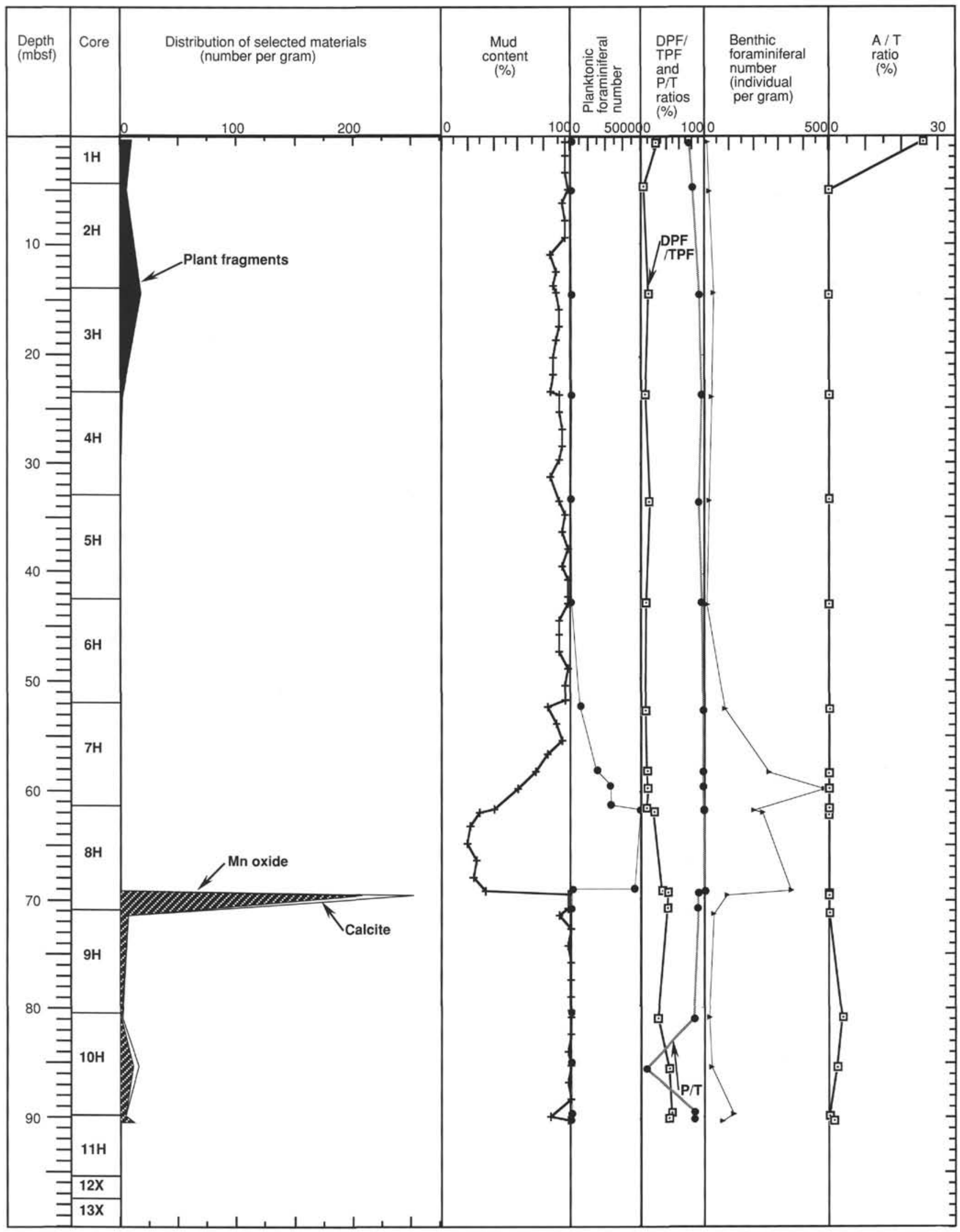

Figure 4. Stratigraphic distribution of selected sedimentary constituents, mud content, planktonic foraminiferal number, benthic foraminiferal number, damaged planktonic foraminifers/total planktonic foraminifers ratio, planktonic foraminifers/total foraminifers ratio, and agglutinated foraminifers/total benthic foraminifers ratio at Site 828 . 


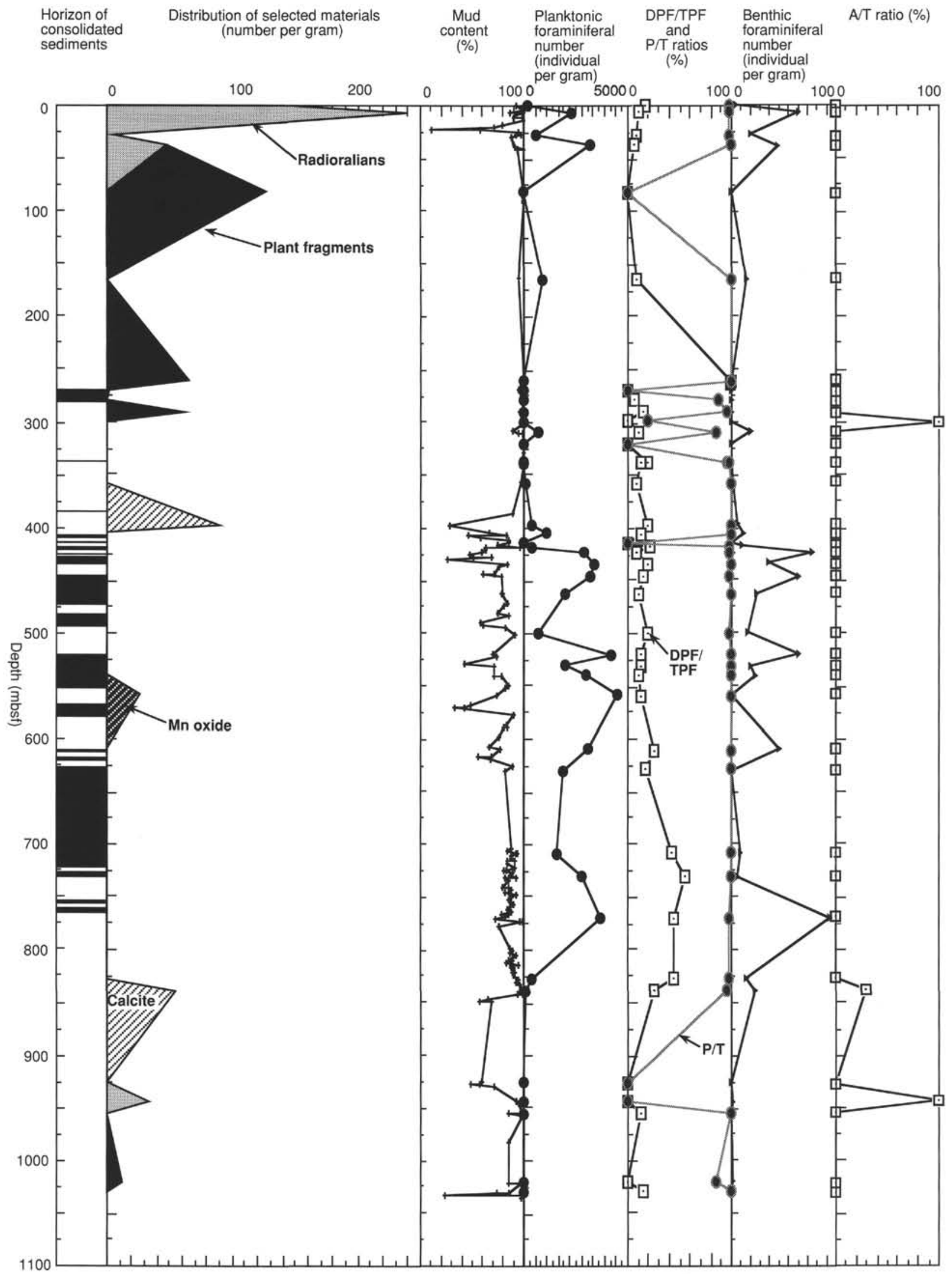

Figure 5. Stratigraphic distribution of selected sedimentary constituents, mud content, planktonic foraminiferal number, benthic foraminiferal number, damaged planktonic foraminifers/total planktonic foraminifers ratio, planktonic foraminifers/total foraminifers ratio, and agglutinated foraminifers/ total benthic foraminifers ratio at Site 832 . 


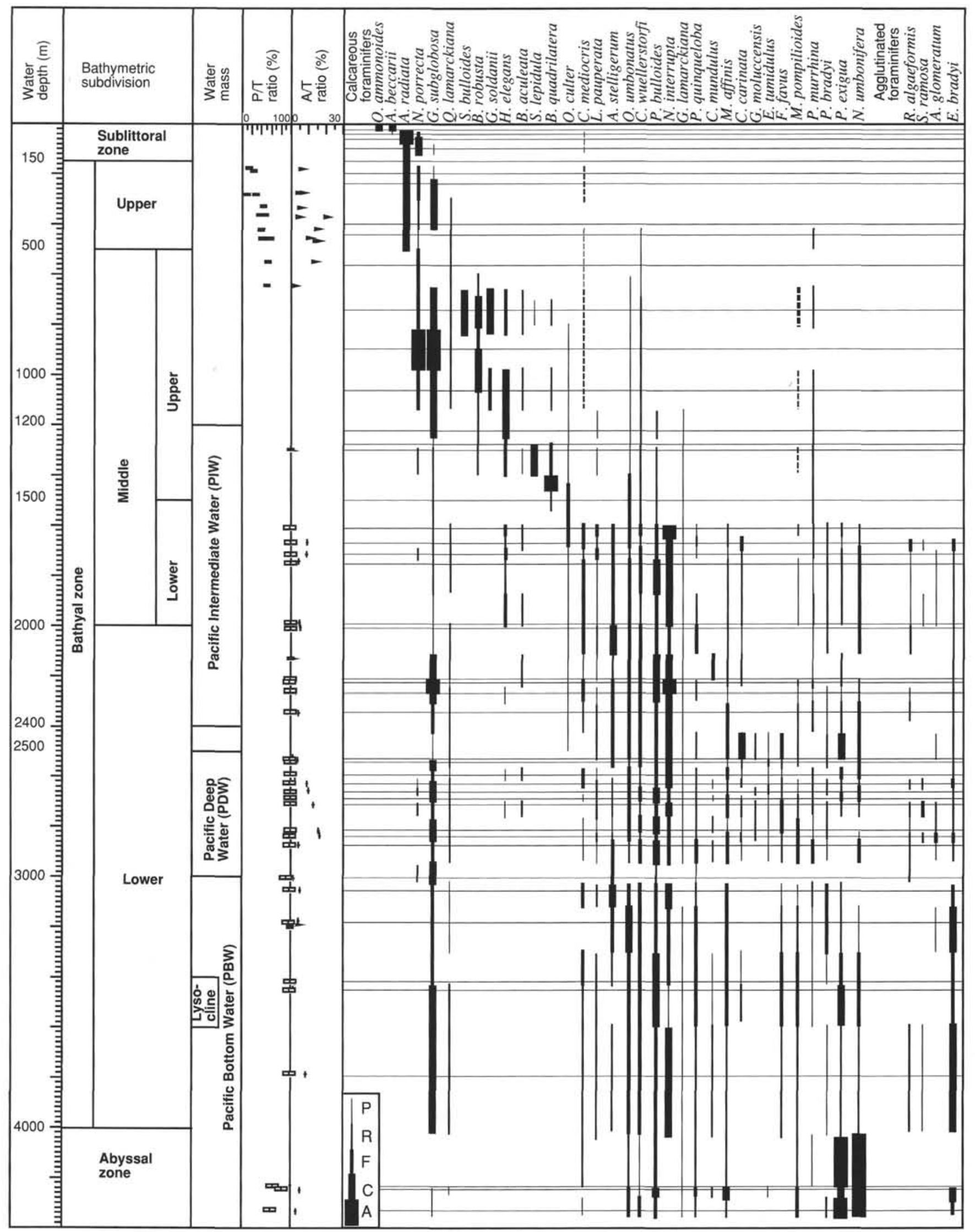

Figure 6. General bathymetric zonation, generalized water masses, foraminiferal statistics, and depth distribution of major benthic foraminiferal species in the modern tropical Pacific Ocean (Burke, 1981: Ontong Java Plateau area; Kurihara and Kennett, 1986: New Caledonia area; Oki, 1985, 1988: Fiji area). 
variable with a factor loading greater than $10.5 \mid$ can be said to be related to a factor. A sample can be related to a factor by factor scores. A sample is strongly related to a factor when its score exceeds 1.0. A varimax rotation of the factors produces a less abstract result because each varimax factor is constrained to have a faunal composition very similar to that actually observed in at least one sample (Davis, 1973).

In this study, benthic foraminifers from the Cenozoic sediment at Sites $827,828,829$, and 832 were identified and listed in Tables 2 through 5 (back pocket fold out, this volume). Factor analysis with a varimax rotation was performed to detect major environmental factors that likely controlled the distribution of benthic foraminifera in the Cenozoic sequences analyzed at Sites $827,828,829$, and 832 . The data matrix for this analysis is composed of 99 samples (61 at Site 827 and 829,17 at Site 828, and 21 at Site 832) selected from a total of over 600 sediment samples examined. In addition, the matrix includes 58 species at Sites 827 and 829,45 species at Site 828 , and 49 species at Site 832 , out of 427 benthic foraminifer taxa identified, which are represented by five or more individuals in two or more samples at each site listed in Tables 2 through 5. Statistical analysis was performed using a Macintosh personal computer and US SPSS, Inc., software.

Factor analysis identified five factors that account for $70.2 \%$ of the variability of data analyzed from Sites 827 and 829 (Table 6), 4 factors that account for $59.0 \%$ of the variability at Site 828 (Table 7), and 6 factors that account for $53.2 \%$ of the variability at Site 832 (Table 8). Tables 9, 10, and 11 list the varimax factor scores for each species within each factor at Sites 827 and 829,828 , and 832, respectively.

\section{Sites 827 and 829}

The stratigraphic distributions of the factor loadings and assemblages in the sequences at Sites 827 and 829 are illustrated in Figures 7 and 8 . Assemblage I is recognized by Factor 1 at only Site 829 , and it accounts for $22.7 \%$ of the variance. This assemblage is characterized by abundant Globocassidulina subglobosa, which dominates Unit II (Pliocene) and III (Oligocene) at Site 828. G. subglobosa is associated with the shallow-water mass of the modern Pacific Ocean (Woodruff, 1985), whereas Site 829 is currently located beneath the Pacific Bottom Water at a depth of $2900 \mathrm{~m}$. In addition, Assemblage I is found in Unit II and within the interval of Units V to XI of Hole 829A. The samples from these lithostratigraphic units, which have high positive first factor loading, are composed of Eocene to Oligocene sediment accompanied with manganese micronodules. This suggests that Factor 1 reflects the downslope transport of Eocene and Oligocene sediments from the North d'Entrecasteaux Ridge.

Assemblage II is represented by Factor 2, and accounts for $21.8 \%$ of the variance. This assemblage is dominated by Valvulineria gunjii and is distributed in Pleistocene and Holocene strata at Sites 827 and 829, which are located beneath the Pacific Deep Water. On the other hand, the $V$. gunjii assemblage is poorly represented in Quarternary sediment at Site 832, which is situated at a depth of $3089 \mathrm{~m}$. Thus, the $V$. gunjii assemblage indicates the boundary between the Pacific Deep Water (PDW) and Pacific Bottom Water (PBW). The subordinate species, Uvigerina peregrina, is also common in sediment beneath the PBW (Hermelin, 1989). Factor 2 is thus thought to express the boundary between the PDW and PBW.

The distribution of Assemblage III, which accounts for $6.4 \%$ of the variance, is restricted to Site 827 . This assemblage is recognized by Factor 3, and is composed of Cassidulina norvangi, Trifarina angulosa, and Gyroidinoides nipponicus. These three species occur widely in the bathyal zone of the modern Pacific Ocean. Thus, the third factor loading is related to neither water depth nor water masses. $C$. norvangi occurs abundantly in association with low oxygen bottom waters in the modern northwest Pacific Ocean (Nishi, 1992).

This study also examined the relationship between organic carbon and sediment character. High abundance of organic carbon may be implied by the presence of plant fragments as found in the intervals from 37 mbsf (Sample 134-827A-5H-01, 50-54 cm) to $67.5 \mathrm{mbsf}$
Table 6. Summary of factor analysis at Sites 827 and $\mathbf{8 2 9}$.

\begin{tabular}{crrc}
\hline Factor & Eigenvalue & $\begin{array}{c}\text { Percent } \\
\text { of variable }\end{array}$ & $\begin{array}{c}\text { Cumulative } \\
\text { percentage }\end{array}$ \\
\hline 1 & 12.05218 & 22.7 & 22.7 \\
2 & 11.57922 & 21.8 & 44.6 \\
3 & 3.41241 & 6.4 & 51.0 \\
4 & 2.35159 & 4.4 & 55.5 \\
5 & 1.86327 & 3.5 & 59.0 \\
\hline
\end{tabular}

Table 7. Summary of factor analysis at Site 828 .

\begin{tabular}{cccc}
\hline Factor & Eigenvalue & $\begin{array}{c}\text { Percent of } \\
\text { variable }\end{array}$ & $\begin{array}{c}\text { Cumulative } \\
\text { percentage }\end{array}$ \\
\hline 1 & 6.48879 & 38.2 & 38.2 \\
2 & 2.37768 & 14.0 & 52.2 \\
3 & 1.84595 & 10.9 & 63.0 \\
4 & 1.29921 & 7.6 & 70.7 \\
\hline
\end{tabular}

Table 8. Summary of factor analysis at Site $\mathbf{8 3 2}$.

\begin{tabular}{cccc}
\hline Factor & Eigenvalue & $\begin{array}{c}\text { Percent of } \\
\text { variable }\end{array}$ & $\begin{array}{c}\text { Cumulative } \\
\text { percentage }\end{array}$ \\
\hline & & & \\
1 & 4.09185 & 19.5 & 19.5 \\
2 & 2.10145 & 10.0 & 29.5 \\
3 & 1.85353 & 8.0 & 38.3 \\
4 & 1.66389 & 7.9 & 46.2 \\
5 & 1.45706 & 6.9 & 53.2 \\
6 & 0.90217 & 4.3 & 57.5 \\
\hline
\end{tabular}

(Sample 134-827A-9H-01, 44-49 cm), and from $81 \mathrm{mbsf}$ (Sample 134-827A-11H-03, 49-51 cm) to 88.3 mbsf (Sample 134-827A-13H01, 49-51 cm) of the Pleistocene strata (Fig. 2). These latter samples are coincident with positive higher values of the third factor as shown in Figure 7. Hence, the prevalence of organic-carbon-rich conditions likely indicate positive factor loading of Factor 3. In turn, organic-rich conditions may have reduced the oxygen content of water immediately overlying sediment and of interstitial waters in sediment.

Assemblage IV is represented by Factor 4 and accounts for $4.4 \%$ of the variance. This assemblage is characterized by the occurrence of Melonis barleeanus and is found only in the Pleistocene and Holocene sediment. $M$. barleeanus is common in sediment beneath the Pacific Bottom Water (Woodruff, 1985). Nuttallides umbonifera, which is common at water depths between the lysocline and the CCD in the $\mathrm{PBW}$, is absent in this assemblage. Assemblage IV is thus regarded as indicative of the upper part of the PBW.

Assemblage $\mathrm{V}$ accounts for $3.5 \%$ of the variance and is marked by Bolivinita quadrilatera and Bulimina aculeata. These two species are abundant in sediment beneath the Pacific Intermediate Water (Cushman, 1942). Thus Factor 5, which is recognized by Assemblage V, is considered to be indicative of the PIW.

\section{Site 828}

Based on the stratigraphic distribution of higher factor loadings, the faunas in the Site 828 sequence are divided into three assemblages: I, II, and III (Fig. 9). Assemblage I is recognized by Factor 1 and occurs in lithostratigraphic Unit III. It accounts for $38.2 \%$ of the variance and is dominated by Turrilina brevispira, which is accompanied by Globocassidulina subglobosa and Stilostomella lepidula. T. brevispira is most common in Paleogene bathyal deposits, but it also occurs in Eocene abyssal paleoenvironments (van Morkhoven et al., 1986). However, the lithofacies accompanying Assemblage I is a nannofossil 
Table 9. Factor scores at Sites 827 and $\mathbf{8 2 9}$.

\begin{tabular}{|c|c|c|c|c|c|}
\hline Species & Factor 1 & Factor 2 & Factor 3 & Factor 4 & Factor 5 \\
\hline Ammobaculites sp. & -0.64026 & -0.08640 & 1.48057 & -0.11110 & 0.06112 \\
\hline Anomalinoides globulosa (Chapman and Parr) & -0.25802 & -0.21195 & -1.46165 & -0.22894 & 0.52295 \\
\hline Astrononion stelligrum (d'Orbigny) & -0.84815 & -1.61777 & 2.77931 & -0.38626 & 1.18904 \\
\hline Bolivina robusta Brady & -0.19496 & 1.39173 & -1.77065 & -0.88250 & -1.16572 \\
\hline B. subangularis leneata (Cushman) & -0.30606 & 0.27071 & -1.88463 & 0.76667 & -0.71263 \\
\hline Bolivinita quadrilatera (Brady) & -0.02211 & 0.26548 & -0.40477 & -0.48961 & 5.62382 \\
\hline Brizalina alata (Seguenza) & -0.26115 & 0.08163 & 2.41010 & 0.69897 & 0.68583 \\
\hline B. hantkeniana (Brady) & -0.27038 & -1.10801 & 2.63937 & 0.18067 & 1.36323 \\
\hline B. karreriana (Brady) & -1.24146 & -2.10030 & 1.67049 & 1.03283 & 1.60097 \\
\hline B. pygmea (Brady) & -0.24245 & -0.34649 & 2.21402 & -0.54413 & -1.50640 \\
\hline B. seminuda (Cushman) & -0.19540 & -0.04988 & 0.15125 & -0.41784 & -1.20688 \\
\hline B. sp. & -0.30230 & -0.18753 & -0.34653 & -0.39691 & -0.38087 \\
\hline Bulimina aculeata d'Orbigny & -1.07579 & 0.77239 & -2.25074 & -1.26492 & 3.46094 \\
\hline B. ampliaperture Belford & 0.00206 & 0.58339 & 0.32599 & -0.44363 & -0.97649 \\
\hline B. glomachallengeri Tjalsma and Lohmann & 1.42323 & 0.06083 & -1.60996 & -0.62891 & -0.91168 \\
\hline B. marginata d'Orbigny & -0.25922 & 1.58309 & -1.96553 & -0.10076 & -0.96051 \\
\hline B. striata d'Orbigny & -0.28150 & -1.03893 & 0.72790 & 0.32135 & -0.62061 \\
\hline Burseolina pacifica (Cushman) & 0.84075 & -0.56360 & -0.83818 & -0.55608 & -0.87589 \\
\hline Cassidulina carinata Silvestri & -0.27122 & 0.44778 & 0.03267 & 0.27197 & -0.83810 \\
\hline C. havanensis Cushman and Bermudez & -0.33756 & -0.78082 & 1.46993 & -0.12024 & 0.00522 \\
\hline C. norvangi Thalmann & -0.24048 & -0.49977 & 4.61784 & -1.23178 & -0.46857 \\
\hline Cibicides wuellerstorfi (Schwager) & -1.22085 & -1.99967 & 0.40479 & 0.35082 & 0.57621 \\
\hline Cibicidoides mediocris (Finlay) & 1.56989 & -0.11668 & -0.57361 & 0.36259 & -0.05883 \\
\hline Ehrenbergina hvstrix Brady & -0.69871 & 0.27264 & 2.90140 & 0.72701 & 0.07199 \\
\hline Fijiella simplex (Cushman) & -0.12225 & -0.21825 & 2.28681 & -0.56720 & -0.59113 \\
\hline Globocassidulina cressa (d'Orbigny) & -0.87587 & -1.90568 & 1.72578 & 0.36660 & 0.57767 \\
\hline G. cf. decorata (Sidebottom) & 0.72127 & -0.27139 & 1.34662 & 0.00434 & -0.18982 \\
\hline G. moluccensis (Germeraad) & -0.26330 & 0.45538 & -1.01391 & -1.15296 & 1.77403 \\
\hline G. mucronata Nomura & 0.52619 & 0.19202 & -2.54382 & -0.74382 & -0.14463 \\
\hline G. ornata (Cushman) & 1.08398 & 0.21643 & -1.77100 & -0.63103 & -0.62591 \\
\hline G. paratortuosa (Kuwano) & -0.45768 & -1.16601 & -3.60627 & -0.48165 & 0.70510 \\
\hline G. subglobosa (Brady) & 6.55854 & 0.39948 & 0.52412 & 0.16208 & 0.34510 \\
\hline G. subtumida (Cushman) & 1.55635 & 0.46972 & -1.56422 & -0.70545 & -0.67340 \\
\hline Gyroidina orbicularis d'Orbigny & 1.53439 & 0.69160 & -4.46278 & -1.21417 & -0.72793 \\
\hline Gyroidinoides lamarckianus (d'Orbigny) & 0.09071 & 0.81404 & -0.83339 & -0.44140 & -1.01606 \\
\hline G. nipponicus (Ishizaki) & -0.30940 & -0.21647 & 3.13782 & 2.27473 & 1.78091 \\
\hline Melonis barleeamus (Williamson) & -0.06671 & -0.34877 & -0.47483 & 5.92740 & -0.31632 \\
\hline M. pacificus (Cushman) & -0.86585 & -0.10062 & -1.41826 & -0.00716 & 1.12283 \\
\hline Oridorsalis tener (Brady) & -0.23092 & 1.06944 & -1.44458 & 1.37665 & -0.80691 \\
\hline O. umbonatus (Reuss) & -0.69965 & -0.67122 & 1.46575 & 0.07880 & 0.42088 \\
\hline Osangularia culter (Parker and Jones) & 0.43765 & -0.45683 & 0.65679 & 0.02412 & -0.29237 \\
\hline Pseudoparrella exigua (Brady) & -0.14680 & 0.03184 & 1.45132 & -0.28614 & -1.21421 \\
\hline Pullenia quinqueloba (Reuss) & -1.96718 & -2.01633 & 2.28425 & 0.71993 & 1.11164 \\
\hline Robulus gibbus d'Orbigny & -0.23219 & 2.24199 & -1.23830 & 0.25929 & -1.45779 \\
\hline Rutherfordoides cornuta (Cushman) & 0.63002 & 1.08663 & -0.54521 & 0.26019 & -2.79421 \\
\hline Sigmavirgulina tortuosa (Brady) & -0.01406 & -1.50206 & -1.40281 & -0.30235 & 0.29389 \\
\hline Sphaeroidina bulloides d'Orbigny & -0.11171 & -0.72262 & 1.50948 & 0.24206 & -1.66314 \\
\hline Stilostomella abyssorum (Reuss) & 0.74903 & 0.26550 & -0.86402 & -0.71043 & -0.30237 \\
\hline S. lepidula (Schwager) & 0.84610 & -0.68374 & -0.17186 & -0.32256 & 0.09814 \\
\hline$S$. sp. A & -0.73518 & -0.05427 & 0.26240 & -0.20314 & -0.16171 \\
\hline Trifarina angulosa (Williamson) & -2.66156 & -1.57137 & 3.22915 & 0.91942 & 1.39169 \\
\hline T. bradyi Cushman & 0.67874 & -0.42975 & 2.48458 & 0.21566 & -0.99570 \\
\hline Turrilina brevispira ten Dam & -0.53895 & 0.02600 & -1.18639 & -0.60816 & 0.12468 \\
\hline Uvigerina hispidocostata Cushman and Todd & 0.25593 & 1.11572 & -1.27229 & -0.06188 & -0.64301 \\
\hline U. peregrina Cushman & 0.38243 & 2.98401 & -4.37684 & -0.87327 & -1.30413 \\
\hline U. proboscidea Schwager & 0.60654 & -0.27436 & -1.83804 & -0.61404 & 0.42123 \\
\hline U. cf. tasmana Boersma & -0.53503 & -1.45115 & -1.37380 & -0.11888 & 0.77696 \\
\hline Valvulineria ginjii Akimoto & -0.53571 & 6.97919 & 0.31839 & 0.30510 & 0.44213 \\
\hline
\end{tabular}

chalk. Modern analogs to the chalk lithofacies are found in the abyssal zone between the lysocline and the CCD (Kennett, 1982). The distribution of the first factor loading coincides with that of the planktonic foraminiferal numbers and P/T ratio, as shown in Figure 3. This coincidence supports the abyssal inference of variance for Factor 1. Therefore, Assemblage I is considered to be indicative of the Oligocene abyssal zone above the CCD.

Assemblage II at Site 828 accounts for $14.0 \%$ of the variance and is represented by Factor 2. This assemblage is dominated by Globocassidulina subglobosa, which occurs abundantly in shallow water in the modern ocean (Woodruff, 1985). Todd (1965) reported that $G$. subglobosa is distributed in water depths of 600 to $1200 \mathrm{~m}$ in the modern Pacific Ocean and occurs in areas of high calcium carbonate concentration surrounding islands and plateaus. This assemblage zone also corresponds to lithostratigraphic Unit II (foraminiferal ooze). Thus, Factor 2 suggests the presence of a shallow-water mass above the PIW surrounding a plateau.

Assemblages III and IV are recognized in Unit I. Assemblages III and IV, accounting for $10.9 \%$ and $7.6 \%$ of the variance, respectively, are represented by Factors 3 and 4 and are dominated by Valvulineria gunjii and Oridorsalis tener, respectively. V. gunjii is common in sediment beneath the boundary between Pacific Deep Water and Pacific Bottom Water. Thus, Factor 3 may imply the presence of the boundary between the PDW and PBW.

No data are available for the modern distribution of $O$. tener in the equatorial Pacific Ocean. However, this species is a typical deep water species and is distributed in the middle bathyal zone of the modern world ocean (e.g., Pflum and Frerichs, 1976; Akimoto, 1990). Although Site 828 is situated in the lower bathyal zone (about $3000 \mathrm{~m}$ in water depth), the sample from the top of the sequence at this site yields abundant $O$. tener. Thus, the fourth factor loading cannot be explained by water depth or water mass. On the other hand, samples having high fourth factor loadings are characterized by low mud content and include many plant fragments. These associations indicate that Assemblage IV was likely derived from the lower middle bathyal zone off Espiritu Santo Island and transported by turbidity currents. Thus, Factor 4 suggests the transport of sedimental organic matter from the island. 
Table 10. Factor scores at Site 828 .

\begin{tabular}{|c|c|c|c|c|}
\hline Species & Factor 1 & Factor 2 & Factor 3 & Factor 4 \\
\hline Astrononion stelligrum (d'Orbigny) & 0.70936 & -0.23461 & 0.05902 & -0.61290 \\
\hline Bolivinita quadrilatera (Brady) & -0.38794 & -0.13707 & 0.16053 & -0.20350 \\
\hline Brizalina alata (Seguenza) & -0.31303 & -0.40886 & -0.10359 & -0.18545 \\
\hline B. macella Belford & -0.38062 & -0.15441 & -0.38503 & -0.23022 \\
\hline Bulimina glomachallengeri $\mathrm{Tj}$ alsma and Lohmann & 0.60771 & -0.61898 & -0.45062 & -0.54389 \\
\hline B. marginata d'Orbigny & -0.20251 & -0.40356 & 0.43235 & -0.02381 \\
\hline Burseolina marshallana (Todd) & -0.34105 & -0.09072 & -0.36124 & -0.22274 \\
\hline B. sp.A & 0.96672 & -0.68839 & -0.33014 & -0.45257 \\
\hline Cassidulina norvangi Thalmann & -0.41872 & -0.41303 & 0.44410 & -0.10592 \\
\hline Chilostomella oolina Schwager & -0.22093 & -0.40444 & 0.34303 & 0.05075 \\
\hline C. ovoidea Reuss & -0.22536 & -0.35188 & 0.47273 & -0.30614 \\
\hline Cibicides wuellerstorfi (Schwager) & -0.76744 & 0.68936 & -0.35113 & -0.09005 \\
\hline Cibicidoides sp. & -0.01492 & -0.56237 & -0.43892 & -0.17216 \\
\hline Ehrenbergina bicornis $\mathrm{Brady}$ & -0.29787 & -0.23593 & -0.37479 & -0.26722 \\
\hline Evolvocassidulina brevis (Aoki) & -0.38915 & -0.08309 & -0.10543 & -0.21743 \\
\hline E. cf. brevis (Aoki) & -0.49368 & -0.04718 & -0.36122 & -0.02272 \\
\hline Gavelinopsis praegeri (Heron-Allen and Earland) & -1.00635 & 1.55152 & -0.30993 & -0.25653 \\
\hline Globobulimina pacifica Cushman & -0.18294 & -0.31809 & 0.87126 & -0.37089 \\
\hline G. pupoides (d'Orbigny) & -0.19860 & -0.40340 & 0.41207 & -0.02676 \\
\hline Globocassidulina brocha (Poag) & -0.49667 & 0.20321 & -0.25639 & -0.31173 \\
\hline G. cressa (d'Orbigny) & -0.50757 & 0.08155 & -0.36869 & -0.07984 \\
\hline G. moluccensis (Germeraad) & -0.59469 & 0.50709 & -0.37710 & 1.28479 \\
\hline G. mucronata Nomura & -0.69399 & 0.86417 & -0.24885 & 0.52597 \\
\hline G. ornata (Cushman) & -0.44813 & -0.00586 & -0.39929 & -0.23390 \\
\hline G. paratortuosa (Kuwano) & -0.40899 & 0.08598 & -0.34169 & -0.12438 \\
\hline G. parviapertura Nomura & -0.26861 & -0.20451 & -0.19656 & 0.24850 \\
\hline G. subglobosa (Brady) & 2.83793 & 5.29493 & 0.17484 & 0.34131 \\
\hline G. subtumida (Cushman) & -0.36271 & -0.16901 & -0.40310 & -0.22921 \\
\hline Gyroidina orbicularis d'Orbigny & -0.07816 & -0.37538 & -0.33520 & -0.14883 \\
\hline Gyroidinoides lamarckianus (d'Orbigny) & 0.09532 & -0.43016 & 0.51044 & -0.29737 \\
\hline G. nipponicus (Ishizaki) & -0.18997 & -0.50658 & -0.19290 & 0.98211 \\
\hline Nuttallides umbonifera (Cushman) & -0.89994 & 1.05028 & -0.20784 & -0.05453 \\
\hline Oridorsalis tener (Brady) & 0.12320 & -0.56560 & 0.10992 & 5.55251 \\
\hline O. umbonatus (Reuss) & 1.30841 & -0.28516 & -0.31582 & -0.92717 \\
\hline Osangularia culter (Parker and Jones) & -0.26802 & -0.08055 & -0.36031 & -0.29089 \\
\hline Paracassidulina neocarinata (Thalmann) & -0.34778 & -0.05089 & -0.36548 & -0.24305 \\
\hline Parafissurina pseudomarginata (Buchner) & -0.42422 & 0.16927 & -0.34264 & -0.36252 \\
\hline Pseudoparrella exigua (Brady) & -0.38293 & -0.08912 & -0.12444 & 0.26779 \\
\hline Pullenia bulloides (d'Orbigny) & 0.56417 & -0.10472 & -0.36258 & -0.49068 \\
\hline Stilostomella lepidula (Schwager) & 1.66359 & -0.52302 & -0.34140 & -0.43209 \\
\hline Tosaia hanzawai Takayanagi & -0.47879 & 0.15190 & -0.34110 & -0.23752 \\
\hline Turrilina brevispira ten Dam & 4.62893 & -1.69459 & -0.26532 & 0.20433 \\
\hline Uvigerina hispidocostata Cushman and Todd & -0.22093 & -0.40444 & 0.34303 & -0.05075 \\
\hline U. proboscidea Schwager & -0.54092 & 0.46402 & -0.34365 & -0.29660 \\
\hline Valvulineria gunjii Akimoto & -0.05123 & -0.06767 & 5.72909 & -0.23459 \\
\hline
\end{tabular}

\section{Site 832}

The distribution of the factor loadings in the Neogene sequence at Site 832 is illustrated in Figure 10; six assemblages are recognized in this Neogene sequence. Assemblage I, which is represented by Factor 1 , accounts for $19.5 \%$ of the variance and is characterized by Cibicides wuellerstorfi and Gavelinopsis praegeri. Assemblage I is recognized in Pleistocene sediments from 397 to $461 \mathrm{mbsf}$ and at $540 \mathrm{mbsf}$. The upper and lower depth limits of $G$. praegeri in the modern equatorial Pacific Ocean are $1100 \mathrm{~m}$ and $2000 \mathrm{~m}$ (Todd, 1965). C. wuellerstorfi is abundant below $1400 \mathrm{~m}$ water depth near the upper limit of the Pacific Intermediate Water (Fig. 6). Hermelin (1989) reported that $C$. wuellerstorfi is associated with the deep oxygen minimum layer of the PIW. Thus, Factor 1, represented by Assemblage I, is likely related to the presence of the PIW.

Assemblage II accounts for $10.0 \%$ of the variance and is marked by abundant Globocassidulina subglobosa accompanied by Cibicidoides mediocris. This assemblage is recognized by Factor 2 and is distributed in Pleistocene strata at this site. G. subglobosa is abundant in shallow waters but $C$. mediocris is common in deep waters (Woodruff, 1985). Thus, the second factor loading is not related to either water depth or water mass. According to sediment descriptions at this site (Collot, Greene, Stokking, et al., 1992d), many slumps occur in the middle and lower parts of the Pleistocene strata, which agrees with horizon having the high positive second factor loading. Thus, Factor 2 may reflect a transported fauna.
Assemblage III in Factor 3 accounts for $8.8 \%$ of the variance and is composed of Melonis sphaeroides and Melonis barleeanus. $M$. sphaeroides is restricted to the abyssal zone in the modern Pacific Ocean (Hasegawa, 1984), and M. barleeanus was common in sediment beneath the Pacific Bottom Water during the Miocene (Woodruff, 1985). Thus, Factor 3 is thought to indicate the PBW.

The fourth factor accounts for $7.9 \%$ of the variance and is dominated by Rhabdammina abyssorum (Assemblage IV). $R$. abyssorum is common at depths below the lysocline in the modern Pacific Ocean (Akimoto, 1990) and is abundant at depths below the CCD (Nienstedt and Arnold, 1988). In addition, the intervals represented by high positive Factor 4 loading accord with the distributions of low P/T and high $\mathrm{A} / \mathrm{T}$ ratios as shown in Figure 5. Thus, Factor 4 is thought to indicate deposition below the lysocline and/or the CCD.

Assemblage $\mathrm{V}$ is represented by the occurrence of Tosaia hanzawai and Globocassidulina moluccensis and accounts for $6.9 \%$ of the variance. This assemblage is recognized by Factor 5 . In the modern ocean, $T$. hanzawai dominates environments between depths of $3000 \mathrm{~m}$ and $4000 \mathrm{~m}$ (Akimoto, 1990). In addition, G. moluccensis is restricted to areas beneath the Pacific Deep Water, as shown in Figure 6. Thus, Assemblage V is related to the PDW.

Assemblage VI, which is characterized by the occurrence of Nuttallides umbonifera, is recognized by Factor 6 and accounts for $4.3 \%$ of the variance. $N$. umbonifera occurs most abundantly in sediment beneath the Pacific Bottom Water (Burke, 1981). Hermelin (1989) reported that this species is most common on the seafloor 
Table 11. Factor scores at Site 832.

\begin{tabular}{|c|c|c|c|c|c|c|}
\hline Species & Factor 1 & Factor 2 & Factor 3 & Factor 4 & Factor 5 & Factor 6 \\
\hline Marsipella cylindrica Brady & -0.54108 & -0.38695 & -0.32957 & 0.12509 & -0.32587 & -0.33208 \\
\hline Rhabdammina abyssorum M.Sars & -0.36682 & -0.37933 & -0.09329 & & -0.40904 & -0.11662 \\
\hline Trochammina globigeriniformis (Parker and Jones) & -0.57684 & -0.39388 & -0.32835 & 0.32114 & -0.37619 & -0.31375 \\
\hline Astrononion stelligrum (d'Orbigny) & 2.07122 & -0.48591 & -0.19900 & -0.35518 & -0.22796 & 0.29526 \\
\hline Bolivinita quadrilatera (Brady) & -0.50302 & -0.34999 & -0.34097 & -0.13822 & -0.26076 & -0.39236 \\
\hline Bulimina rostrata Brady & -0.41780 & -0.21085 & -0.47683 & -0.37150 & -0.28674 & 0.05524 \\
\hline Chilostomella ovoidea Reuss & -0.52160 & -0.33715 & & -0.06667 & -0.28051 & -0.40548 \\
\hline Cibicides robertsonianus (Karrer) & -0.43617 & 0.13032 & -0.35939 & -0.48073 & -0.33114 & 0.03039 \\
\hline C. wuellerstorfi (Schwager) & 278452 & 1.75110 & 0.85498 & -1.04859 & -0.42782 & -0.53905 \\
\hline Cibicidoides mediocris (Finlay) & -0.62513 & 2.52 & & -0.9 & -0.2 & -0.74859 \\
\hline C. mundulus (Brady, Parker and Jones) & 1.13492 & -0.51882 & 0.38927 & 0.02735 & & -0.95661 \\
\hline Dentalina spp. & 0.39309 & -0.11262 & -0.05775 & -0.19299 & -0.36249 & -0.74876 \\
\hline Eponides tumidulus (Brady) & -0.33737 & -0.14300 & -0.78844 & -0.28380 & 0.12955 & -0.34722 \\
\hline assidulina brevis (Ao & -0.39769 & 0.48284 & -0.15748 & -0.09125 & -0.27065 & -0.34307 \\
\hline Gave & 2.95705 & -0.24 & -0.1 & -0.3 & -0 . & 875 \\
\hline essa (d'Orbigny) & -0.40 & -0.1 & & -0 . & -0 . & 0.16123 \\
\hline G. elegans (Sidebottom) & -0.48613 & -0.15918 & & -0.33 & -0.24969 & -0.42064 \\
\hline raad) & 18 & -0.6 & & -0 . & & -0 . \\
\hline & 6 & -0.4 & & -0 . & -0 . & -0. \\
\hline G. & -0.1 & 0.0 & & -0 . & -0. & -0 . \\
\hline G. $p$ & -0.43721 & -0.27 & & -0.3 & -0.2 & 375 \\
\hline Vakamura) & -0.04474 & -0.30 & -0 . & $-0.2-2$ & -0 . & -0 \\
\hline G. $p$ & 1 & -0.4 & & & -0. & -0.2 \\
\hline$G$. s & -0.56 & 4.60 & & & & 0.8 \\
\hline G.s & -0.48337 & -0.19 & -0 . & -0.3 & -0.2 & -0.41199 \\
\hline Gyro & 0.32 & -0.3 & -0 . & -0.3 & -0.3 & 0.23666 \\
\hline Gyr & 08 & -0.4 & & & & 853 \\
\hline Melo & 61197 & -0.7 & & -0.5 & -0.4 & 0.44862 \\
\hline M. $p$ & -0.55778 & -0.14 & -0.2 & -0.29 & & -0.46553 \\
\hline$M, s$ & -0.66295 & 0.091 & & 0.0 & -0.3 & 0.33192 \\
\hline Nod & 6 & 6 & & & & -0 . \\
\hline Nuttall & 1 & -0.26744 & -0.46 & -0.32 & -0.82 & 4.40458 \\
\hline Oridor & -0.49558 & -0.35 & -0.338 & -0.16 & -0.25286 & -0.38711 \\
\hline$O . u$ & 2.19306 & 0.12 & -0.1 & & & 1.69428 \\
\hline Parrelloide. & -0.63 & -0.25 & & -0.2 & & -0.49111 \\
\hline Ple & & & & & -0 . & -0 . \\
\hline P. brevis & -0.000 & -0.69 & -0.0 & -0.24 & -0.40 & 0.99951 \\
\hline Pseudop & 0.658 & -0.415 & -0.11 & 1.17 & -0.19 & -0.42294 \\
\hline Pullenia & 2.38368 & -0.02 & & & & -0.13482 \\
\hline & 0.36465 & & -0.33803 & -0.14356 & -0.14800 & -0.43969 \\
\hline P. s & -0.42 & -0.23 & -0.45 & -0.35 & -0.27905 & 0.00224 \\
\hline Pyrgo lucernula (Schwager) & -0.79894 & -0.49366 & 1.00225 & -0.06542 & -0.04612 & -0.05569 \\
\hline P. murrhina (Schwager) & -0.01590 & -0.21245 & -0.75094 & -0.29774 & -0.11489 & -0.31096 \\
\hline Quinqueloculina lamarckian & -0.44844 & -0.43108 & 0.69456 & -0.69600 & -0.16816 & -0.32064 \\
\hline & & & & & -0 . & -0.16078 \\
\hline S. I & & & -0.3 & -0 . & -0.5 & 0.56732 \\
\hline Tosail & -0.160 & 0.03 & 0.81 & 0.4. & 5.12806 & 0.59270 \\
\hline Uvigerina hispidocostata Cushr & -0.33334 & -0.44516 & -0.42817 & -0.54232 & 0.83846 & -0.49596 \\
\hline U. proboscidea Schwager & -0.73465 & 1.96284 & -0.49796 & -0.34549 & -0.09675 & -1.03358 \\
\hline
\end{tabular}

between the lysocline and the CCD. Factor 6 implies the PBW at depths between the lysocline and the CCD.

\section{PALEOENVIRONMENTAL INTERPRETATION}

\section{Paleobathymetric Models}

The paleodepths or paleobathymetry in the Vanuatu region during the Neogene have been evaluated on the basis of the relationship between the distributions of benthic foraminiferal assemblages and water masses (e.g., Figs. 6 and 11). Any shift in identified benthic foraminiferal assemblages and paleoenvironments implies significant variations of major physical parameters associated with the stratified nature of the water column. In turn, these faunal variations provide the basic criteria for understanding Neogene paleobathymetric and depositional history.

Nine paleoenvironments have been deduced through interpretation of sedimentological properties and ecological data on modern benthic foraminifers. Each paleoenvironment is associated with a particular benthic foraminiferal biofacies (Fig. 11). With the exceptions of the Quarternary Valvulineria gunjii biofacies and the Eocene Turrilina brevispira biofacies, all of the biofacies recognized in Neogene and Quaternary sediment at Sites $827,828,829$, and 832 can be recognized in the modern tropical Pacific Ocean and have established bathymetric distributions.

Valvulineria gunjii dominates faunas from the top of the sequence at Sites 827 (2803.4 m water depth) and 829 (2905.2 m water depth), but it is rare at Sites 828 (3086.7 $\mathrm{m}$ water depth) and 832 (3089.3 m water depth) under the Pacific Bottom Water, and at Site 833 (2628.5 $m$ water depth) under the Pacific Deep Water. The $V$. gunjii fauna has not been previously reported from the modern Pacific Ocean. However, Sites 827 and 829 are located near the boundary of the PDW and PBW. Thus, the distribution of these fauna species is thought to be related to the boundary between the PDW and PBW.

In addition, the extinct Eocene taxon Turrilina brevispira is most common in bathyal deposits, but also occurs in abyssal sediments (van Morkhoven et al., 1986). In this study, this species was found in Oligocene nannofossil chalks. The chalk samples have smaller planktonic foraminiferal numbers and P/T ratios (Fig. 5). The nannofossil ooze is distributed in the abyssal zone between the lysocline and the CCD in the modern ocean (Kennett, 1982). Cushman (1932, 1933, 1942) and Todd (1965) also reported that nannofossil ooze is distributed from depths of 3250 to $4500 \mathrm{~m}$ in the modern equatorial Pacific Ocean. Thus, this species was likely distributed in the abyssal zone between the lysocline and the CCD during the Oligocene.

\section{Paleobathymetric History of the Vanuatu Region}

The Pliocene through Holocene paleobathymetric history of the Vanuatu region (Figure 12) can be reconstructed through geological analyses, benthic foraminiferal biofacies variations, and sedimentology. Robinson (1969), Mallick and Greenbaum (1977), and Carney (1986) have outlined the basic Neogene depositional environments 
CENOZOIC BENTHIC FORAMINIFERAL BIOSTRATIGRAPHY

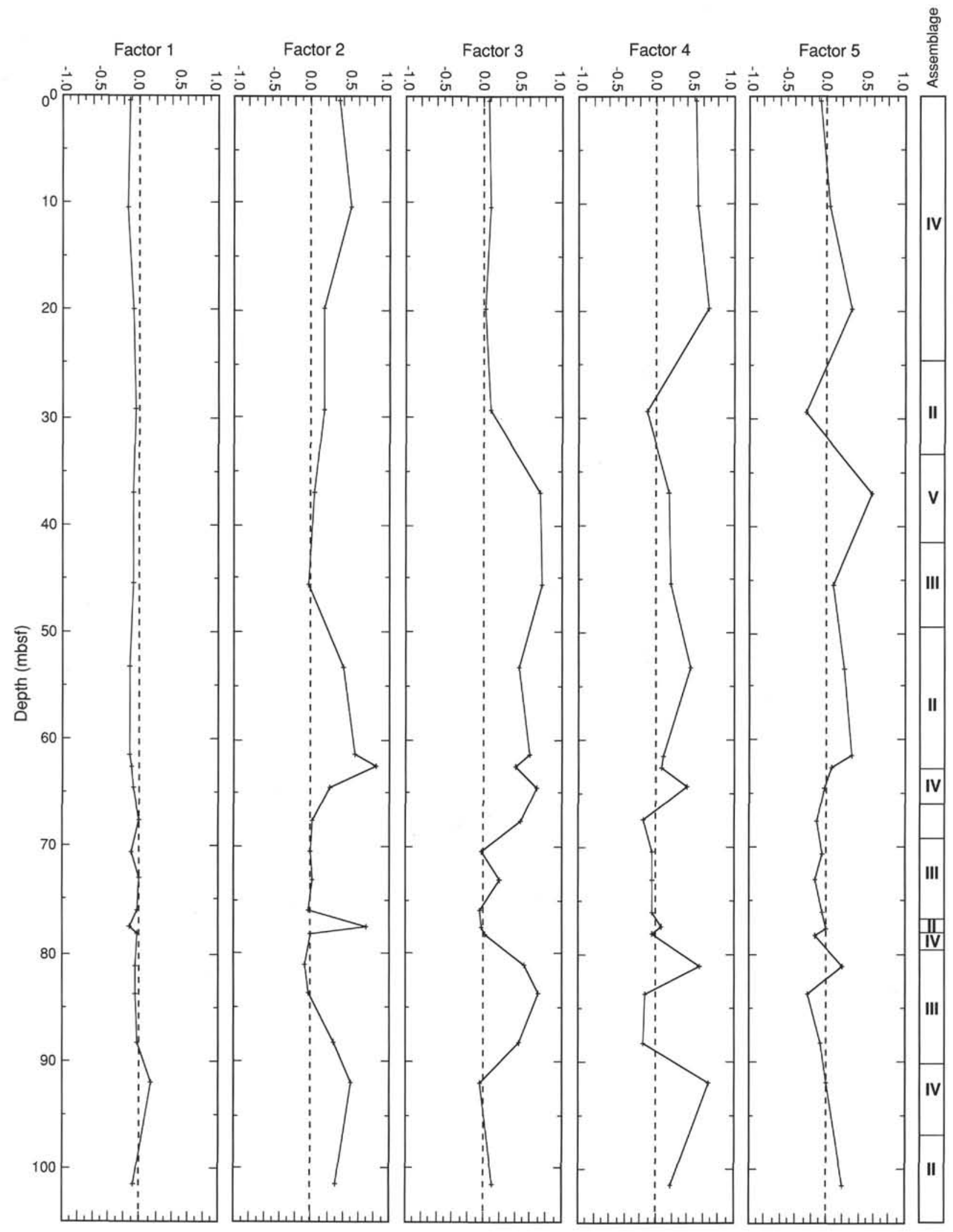

Figure 7. Stratigraphic distribution of varimax loadings for each of the first five factors at Site 827. 


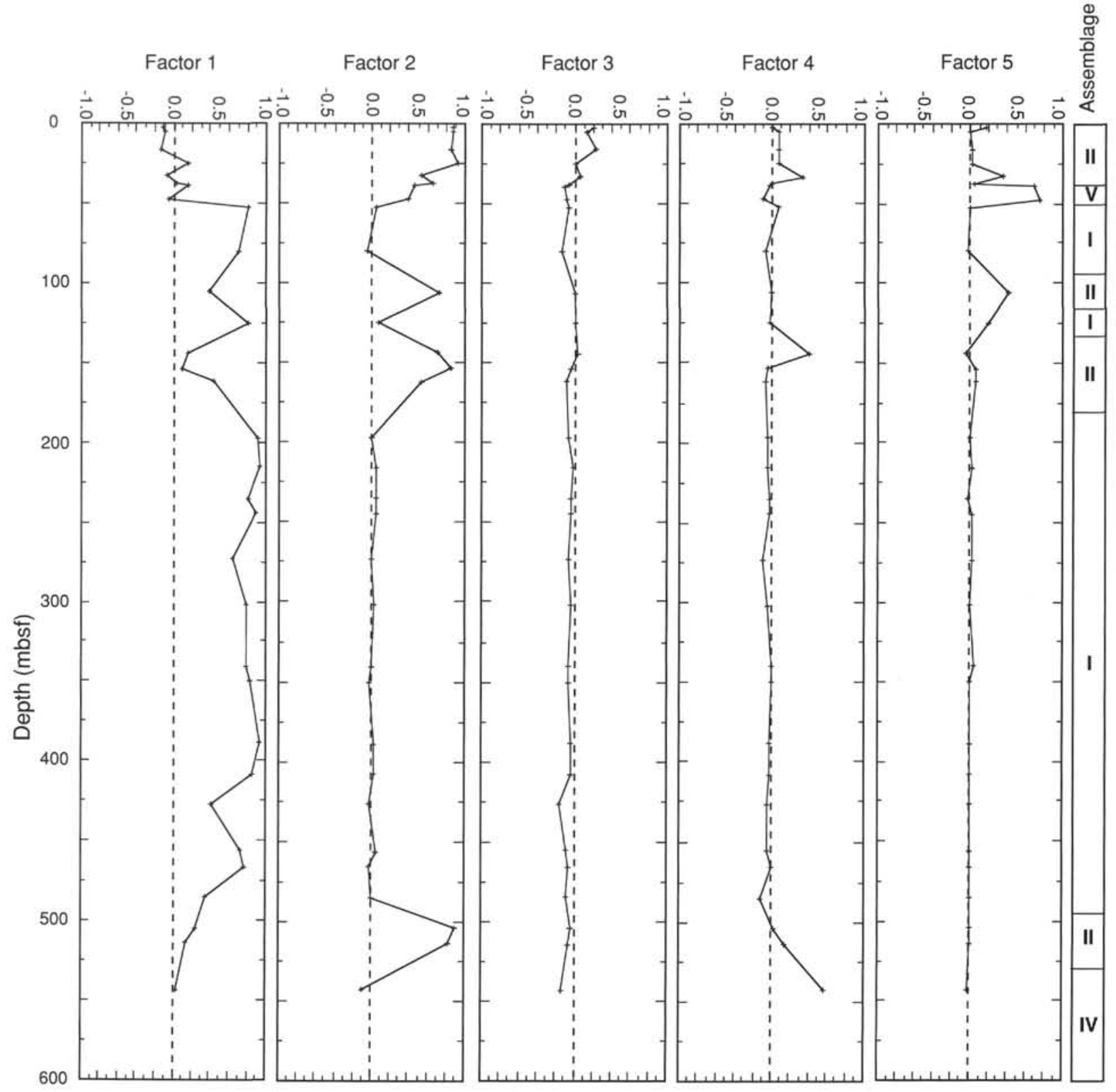

Figure 8. Stratigraphic distribution of varimax loadings for each of the first five factors at Site 829.

of Espiritu Santo and Maewo islands. The following interpretations summarize the paleobathymetric and paleoenvironmental history of the Vanuatu region based primarily on the benthic foraminiferal analysis presented above.

\section{Early Pliocene}

Benthic biofaunas indicate that the North d'Entrecasteaux Ridge was situated at upper bathyal depth $(600-1200 \mathrm{~m})$ during Pliocene and Pleistocene time. However, lower Pliocene sediments in the western part of Espiritu Santo Island were deposited in the sublittoral zone based on the presence of larger benthic foraminiferal species such as Miogypsinoides dehaarti, Miogypsina polymorpha, Miogypsina thecideaeformis, and Lepidocyclina martini in the Tawoli Formation (Robinson, 1969; Mallick and Greenbaum, 1977). Based on the occurrences of the Rhabdammina abyssorum, Nuttallides umbonifera, and Melonis barleeanus-Melonis sphaeroides biofacies in the lower Pliocene strata at Site 832 in ascending order, the seafloor of the North
Aoba Basin was gradually elevated from a depth below the CCD (approximately $4500 \mathrm{~m}$ ) to the middle part of the lower bathyal zone $(3000-3500 \mathrm{~m})$ in the early Pliocene.

Lower Pliocene sediments on Maewo Island are divided into the Tafwutmuto Formation and the Maewo Group (Carney, 1986). The paleodepth of the Tafwutmuto Formation is estimated to be within the range of the Pacific Deep Water (2500-3000 m) based on the occurrences of a typical PDW species such as Favocassidulina favus and Parrelloides bradyi. The Maewo Group is composed of planktonic foraminiferal ooze typical of depths between 1800 and $3000 \mathrm{~m}$ in the modern ocean. Thus, the Maewo Group was likely deposited in the lower part of the middle bathyal zone to the upper part of the lower bathyal zone during early Pliocene time.

\section{Late Pliocene}

The upper part of the Pliocene Tawoli Formation in Espiritu Santo Island yields a rich marine microfauna including bathyal species such 


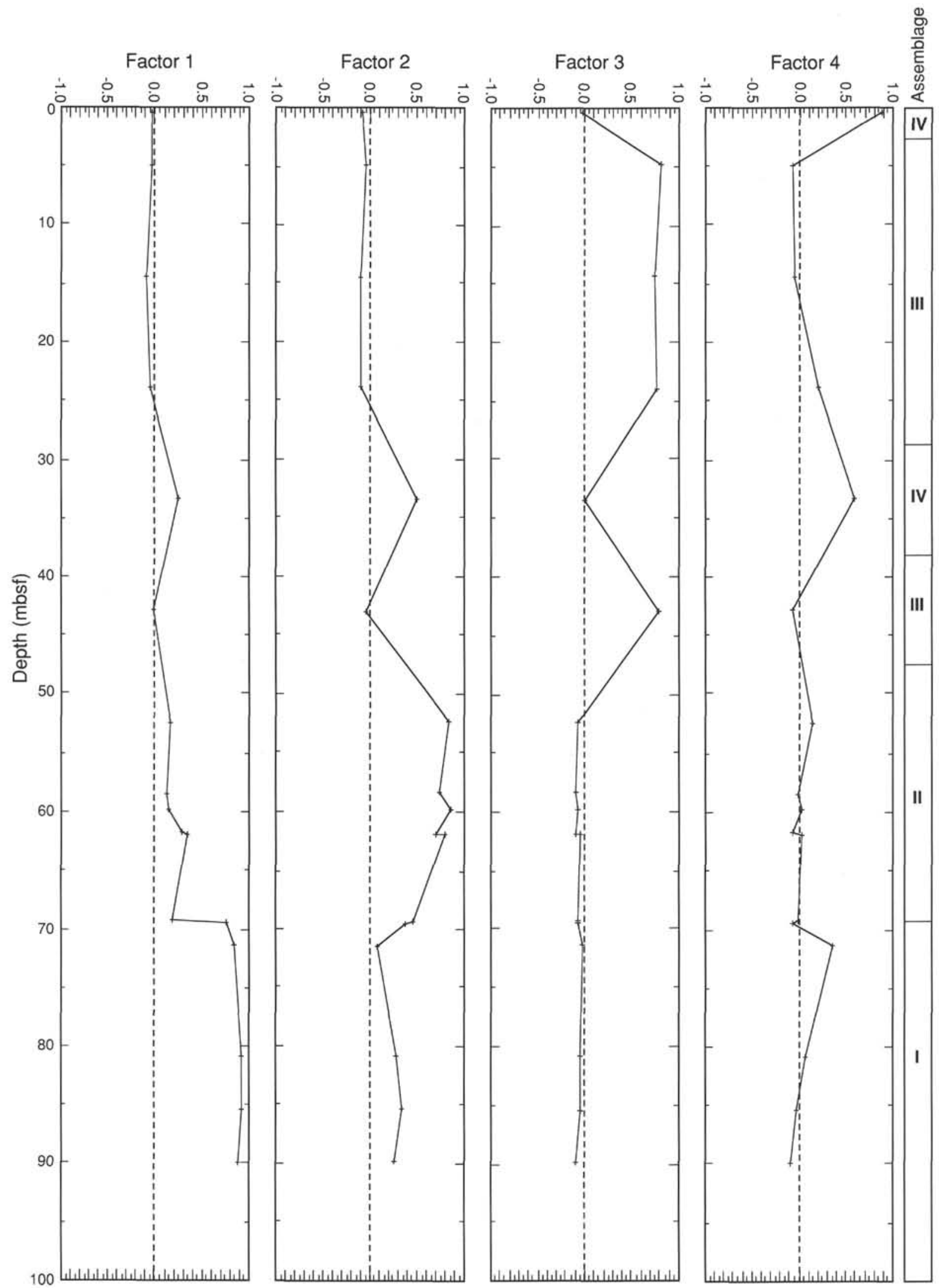

Figure 9. Stratigraphic distribution of varimax loadings for each of the first four factors at Site 828. 


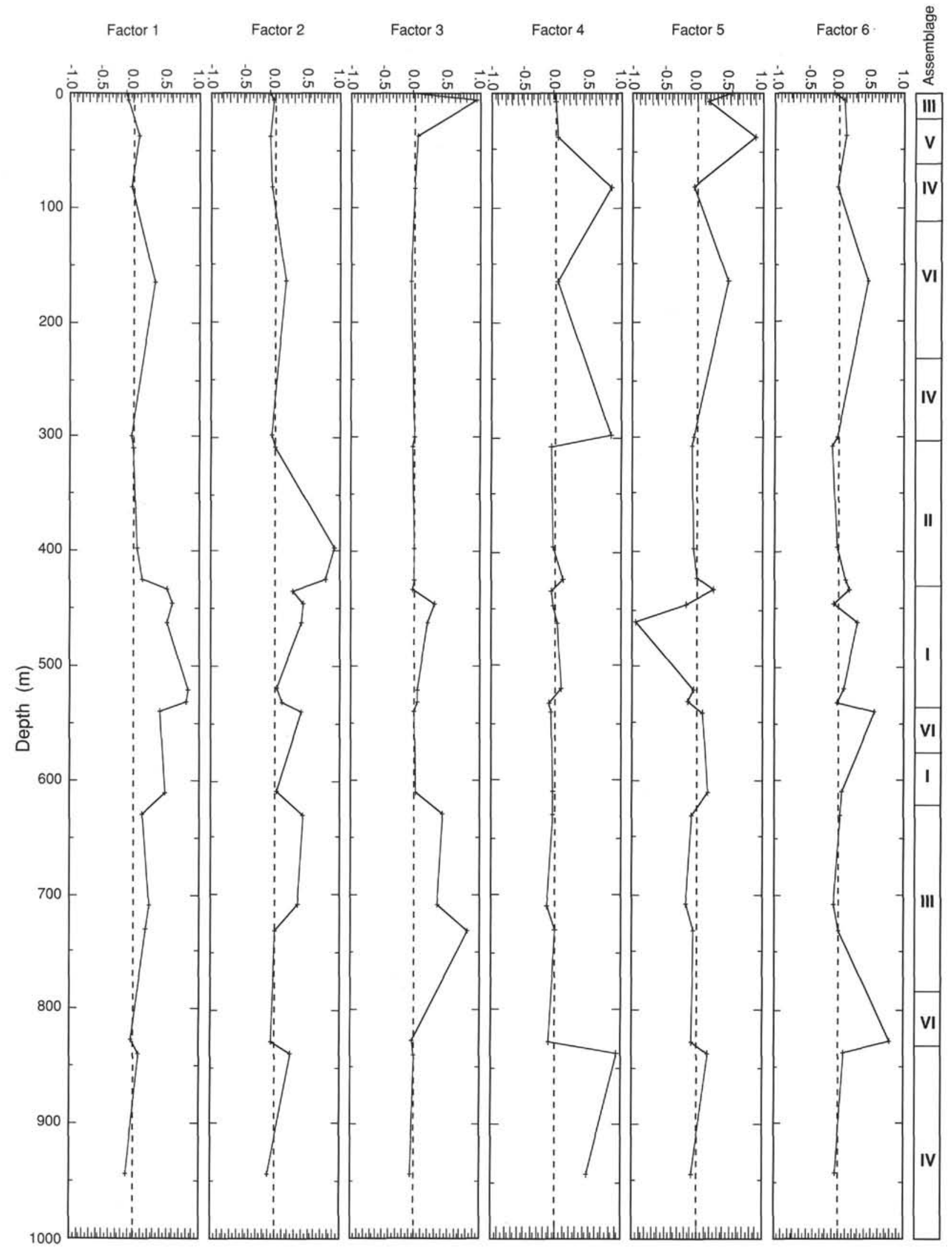

Figure 10. Stratigraphic distribution of varimax loadings for each of the first six factors at Site 832. 


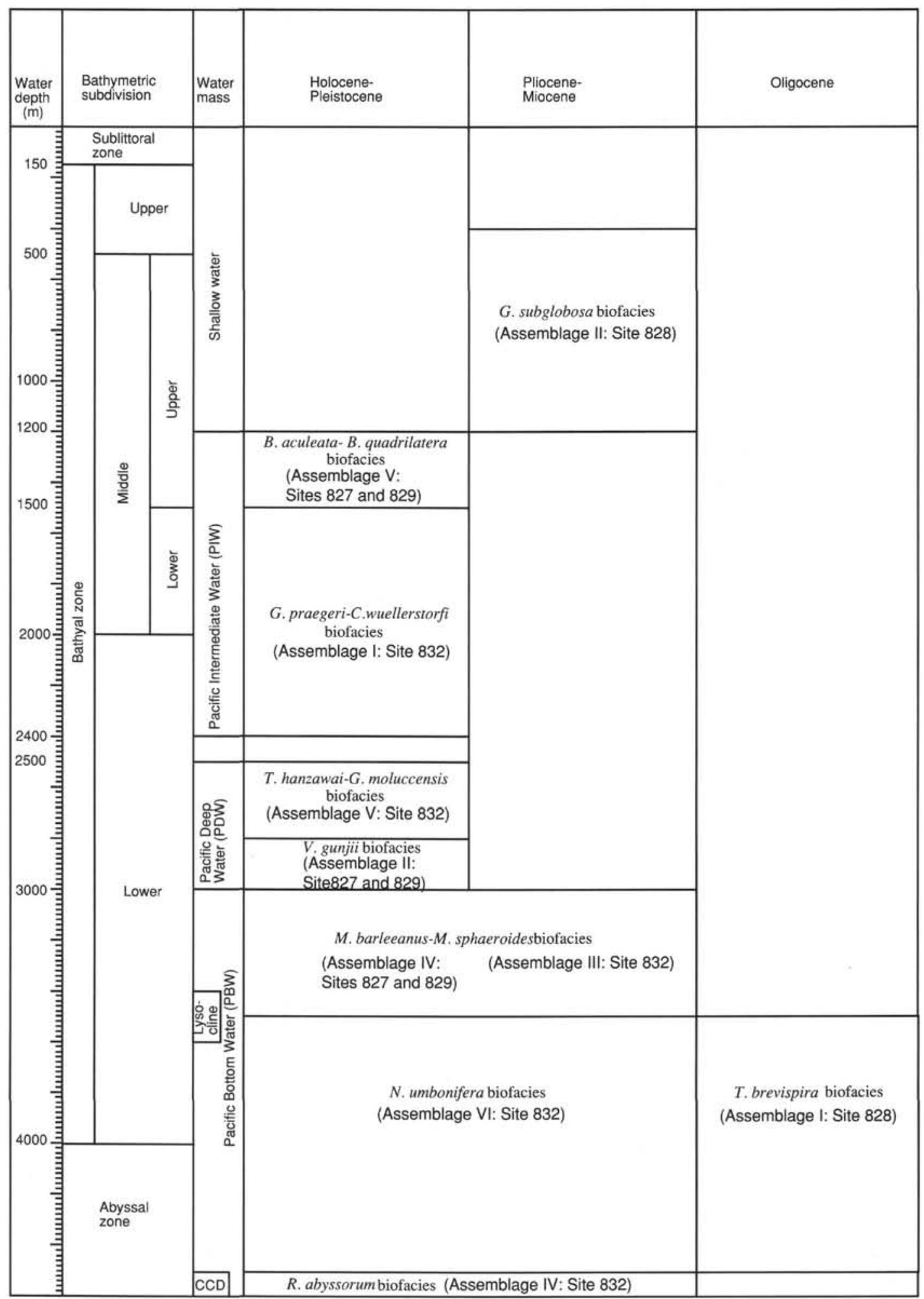

Figure 11. Relationship between bathymetry, water masses, and the distribution of Holocene, Pleistocene, Pliocene, Miocene and Oligocene benthic foraminiferal assemblages at Sites 827, 828, 829, and 832. 

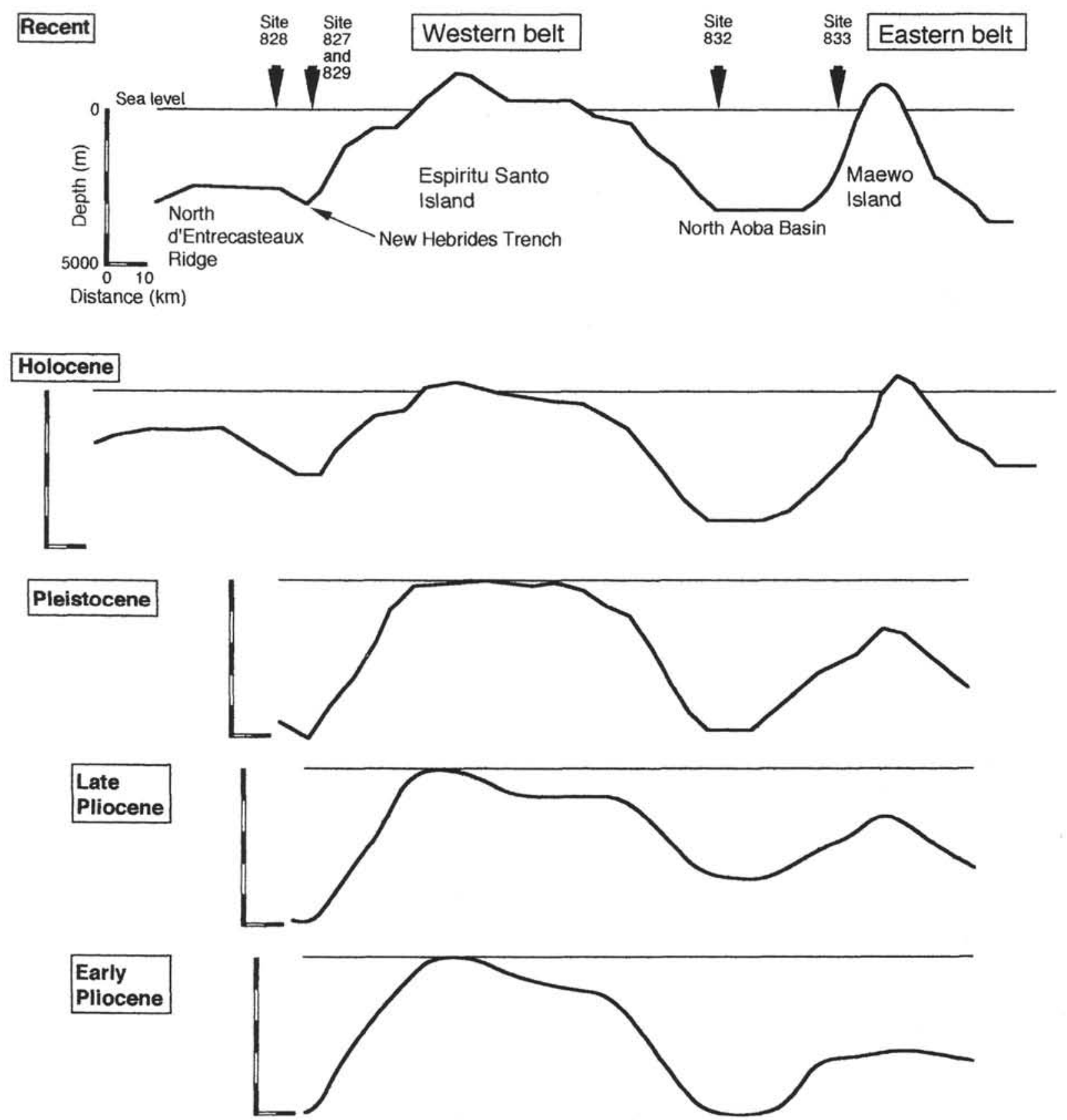

Figure 12. Schematic paleogeography and paleobathymetry of the New Hebrides Island Arc and North d'Entrecasteaux Ridge for the late Miocene/early Pliocene, early/late Pliocene, Pliocene/Pleistocene, and Pleistocene/Holocene.

as Brizalina hantkeniana. The Holocene distribution of this latter species is restricted to the middle bathyal zone (1200-2000 m). Thus, this formation is estimated to have been deposited in the middle bathyal zone. As discussed above, the Pliocene strata at Site 832 accumulated in the lower bathyal zone under the Pacific Bottom Water and at a depth above the lysocline. Thus, the floor of North Aoba Basin likely remained at a depth of 3000 to $3500 \mathrm{~m}$ through the late Pliocene.

Carney (1986) concluded that the Nasawa Formation in Maewo Island was deposited at a water depth shallower than $2550 \mathrm{~m}$ in the middle bathyal zone on the basis of the depth distribution of pteropod ooze in the modern ocean. According to Cushman (1932, 1933, 1942) and Todd (1965), pteropod remains are common at depths of 1000 and $2000 \mathrm{~m}$ in the modern tropical Pacific Ocean. Thus, the upper
Pliocene of Maewo Island was deposited in the lower part of the middle bathyal zone (1000 to $2000 \mathrm{~m}$ ).

\section{Pleistocene}

The paleodepth of Pleistocene sediment accreted to Espiritu Santo Island is interpreted to be the middle part of the lower bathyal zone (2800-3500 $\mathrm{m}$ ) based on the occurrence of the Valvulineria gunjii biofacies and the Melonis barleeanus-Melonis sphaeroides biofacies in Pleistocene sediment cores at Site 829. Judging from Robinson's (1969) data, the western part of Espiritu Santo Island was located in the sublittoral zone $(<150 \mathrm{~m})$, whereas sediment in the eastern part of the island was deposited in the upper bathyal to middle bathyal zone 
(500-1200 m). In addition, Factors 1 and 2, represented by upper and bathyal benthic assemblages, are present in the lower part of Pleistocene strata at Site 832 .

Based on the faunal change from Melonis barleeanus-Melonis sphaeroides biofacies to Nuttallides umbonifera biofacies during the interval between the Pliocene and Pleistocene (ca. 1.9 Ma), the seafloor of the North Aoba Basin apparently subsided 500-1500 m, ultimately reaching abyssal water depths $(4000-4500 \mathrm{~m})$. Pleistocene sediments of Maewo Island were deposited in the sublittoral zone based on the occurrence of many neritic micro- and megafossils (Carney, 1986).

\section{Holocene}

Benthic foraminifers at Site 828 indicate that the basal Holocene strata on the North d'Entrecasteaux Ridge were deposited in the upper bathyal zone (600-1200 m), with the remainder of these sediments deposited in the lower bathyal zone (2800-3000 m). Thus, the paleodepth of these strata changed rapidly from the upper bathyal zone to the lower bathyal zone during the Holocene period.

Sediments comprising the accretionary prism at Sites 827 and 829 off Espiritu Santo Island were deposited in the middle part of the lower bathyal zone ( $2500-3500 \mathrm{~m}$ ) based on the occurrence of the Tosaia hanzawai-Globocassidulina moluccensis biofacies, Valvulineria gunjii biofacies, and Melonis barleeanus-Melonis sphaeroides biofacies. Robinson (1969) constructed the Holocene paleogeography of Espiritu Santo Island by means of lithofacies and the distribution of larger benthic foraminifers. He concluded that the Holocene sediment distributed in the eastern part of this island was deposited in the tidal to upper sublittoral zone during the same period that the western part of island was above sea level.

During the early Holocene, the seafloor of the North Aoba Basin was at abyssal depths (below $4000 \mathrm{~m}$ ) and has rapidly been elevated to its present depth of about $3100 \mathrm{~m}$. According to Carney (1986), Maewo Island was uplifted above sea level before the beginning of the Holocene.

\section{CONCLUSIONS}

Nine benthic foraminiferal biofacies occurring in Oligocene and Miocene to Holocene sediments of the New Hebrides Arc area have been recognized based on sedimentological data and ecological data on modern benthic foraminifers. The paleodepths of the North d'Entrecasteaux Ridge, the eastern continental slope off Espiritu Santo Island, and the seafloor of the North Aoba Basin during Pliocene to Holocene time have been evaluated on the basis of the relationship between the distributions of benthic biofacies. The paleodepth of North d'Entrecasteaux Ridge is estimated to have been at the lower bathyal to abyssal depths during the Oligocene, was uplifted to upper bathyal depths during Pliocene time, and subsided to lower bathyal depths during Pleistocene to Holocene time. The paleodepth of the sea floor of North Aoba Basin is estimated to have been at abyssal depths below the CCD during the early Pliocene time, the middle part of the lower bathyal zone during the late Pliocene and the Holocene times, and the lower part of the lower bathyal zone to abyssal zone during the Pleistocene time.

\section{TAXONOMY}

Benthic foraminiferal species from the Vanuatu area are alphabetically listed below. Some selected species are illustrated with micrographs taken with a scanning electron microscope. The original references are given for each of the species.

Abditodentrix asketocomptella Patterson, 1985

Alabamina dissonata $($ Cushman and Renz $)=$ Pulvinulinella atlantisae Cushman var. dissonata Cushman and Renz, 1948

Alabamina tubulifera (Heron-Allen and Earland) $=$ Truncatulina tubulifera Heron-Allen and Earland, 1915
Allomorphina pacifica Hofker, 1951

Alveolophragmium subglobosum $(\mathrm{G} . \mathrm{O}$. Sars) $=$ Haplophragmium subglo bosa G. O. Sars, 1868

Ammomassilina alveoliformis (Millett) $=$ Massilina alveoliformis Millett, 1898

Ammonia beccarii (Linné) $=$ Nautilus beccarii Linné, 1758

Ammonia beccarii koeboeensis (LeRoy) = Rotalia beccarii (Linné) var. koeboeensis LeRoy, 1939

Amphicoryna bradii (Silvestri $)=$ Nodosariopsis bradii Silvestri, 1902

Amphicoryna hirsuta (d'Orbigny) = Nodosaria hirsuta d'Orbigny, 1826

Amphicoryna pauciloculata $($ Cushman $)=$ Nodosaria pauciloculata Cushman, 1921

Amphicoryna proxima $($ Silvestri $)=$ Nodosaria proxima Silvestri, 1872

Amphicoryna scalaris $($ Batsch $)=$ Nautilus scalaris Batsch, 1791

Amphicoryna separans $($ Brady $)=$ Nodosaria scalaris var. separans Brady, 1884

Amphicoryna subleneata $($ Brady $)=$ Nodosaria hispidula var. subleneata Brady, 1884

Amphistegina madagascariensis d'Orbigny, 1826

Amphistegina radiata (Fichtel and Moll) $=$ Nautilus radiatus Fichtel and Moll, 1798

Anomalinoides cavus Belford, 1966

Anomalinoides glabrata $($ Cushman $)=$ Anomalina glabrata Cushman, 1924

Anomalinoides glabulos $a($ Chapman and Parr $)=$ Anomalina glabulosa Chapman and Parr, 1937

Anomalinoides semicribratus $($ Beckmann $)=$ Anomalina pompilioides Galloway and Heminway var. semicribrata Beckmann, 1954

Articulina mayori Cushman, 1944

Aschemonella scabra Brady, 1879

Astacolus crepidulus (Fichtel and Moll) $=$ Nautilus crepidulus Fichtel and Moll, 1798

Astacolus insolitus $($ Schwager $)=$ Nodosaria insolita Schwager, 1866

Astrononion novozealandicum Cushman and Edwards, 1937

Astrononion stelligerum (d'Orbigny) = Nonionina stelligera d'Orbigny, 1839

Astrononion tumidum Cushman and Edwards, 1937

Baggina philippinensis $($ Cushman $)=$ Pulvinulina philippinensis Cushman, 1921 Bolivina earlandi Parr, 1950

Bolivina rhomboidalis (Millett) = Textularia rhomboidalis Millett, 1899

Bolivina robusta Brady, 1881

Bolivina schwagerina Brady, 188

Bolivina subangularis Brady, 1881

Bolivina subangularis leneata $($ Cushman $)=$ Bolivinita subangularis Brady var. leneata Cushman, 1933

Bolivina spinescens Cushman, 1911

Bolivina subspinescens Cushman, 1922

Bolivinita compressa Finlay, 1939

Bolivinita quadrilatera $($ Schwager $)=$ Textularia quadrilater $a$ Schwager, 1866

Bolivinella elegans Parr, 1932

Brizalina alata $($ Seguenza $)=$ Vulvulina alata Seguenza, 1862

Brizalina capitata $($ Cushman $)=$ Bolivina capitata Cushman, 1933

Brizalina decussata $($ Brady $)=$ Bolivina decussata Brady, 1881

Brizalina hantkeniana $($ Brady $)=$ Bolivina hantkeniana Brady, 1881

Brizalina karreriana $($ Brady $)=$ Bolivina karreriana Brady, 1881

Brizalina karreriana carinata (Millett) $=$ Bolivina karreriana Brady var. carinata Millett, 1900

Brizalina macella Belford, 1966

Brizalina plicatella $($ Cushman $)=$ Bolivina plicatella Cushman, 1930

Brizalina pseudobeyrichi $($ Cushman $)=$ Bolivina pseudobeyrichi Cushman, 1926

Brizalina pygmaea $($ Brady $)=$ Bolivina pygmaea Brady, 1881

Brizalina seminuda $($ Cushman $)=$ Bolivina seminuda Cushman, 1911

Brizalina subreticulata $($ Parr $)=$ Bolivina subreticulata Parr, 1932

Brizalina viscistriata Belford, 1966

Bueningia creeki Finlay, 1939

Bronnimannia hiliotis (Heron-Allen and Earland) $=$ Discorbina hiliotis Heron-Allen and Earland, 1924

Bulimina aculeata d'Orbigny, 1826

Bulimina ampliapertura Belford, 1966

Bulimina fijiensis Cushman, 1933

Bulimina glomachallengeri Tjalsma and Lohmann, 1983

Bulimina marginata d'Orbigny, 1826

Bulimina palmerae Parker and Bermúdez, 1937

Bulimina rostrata Brady, 1884

Bulimina striata d'Orbigny, 1826 


\section{K. АKIMOTO}

Bulimina trinitatensis Cushman and Jarvis, 1928

Bulimina whitei Martin, 1943

Burseolina marshallana (Todd) = Cassidulina marshallana Todd in Cushman, Todd and Post, 1954

Burseolina pacifica $($ Cushman $)=$ Cassidulina pacifica Cushman, 1925

Cassudulina carapitana Hedberg, 1937

Cassidulina carinata Silvestri = Cassidulina laevigata d'Orbigny var. cari nata Silvestri, 1896

Cassudulina havanensis Cushman and Bermúdez, 1936

Cassidulina norvangi Thalmann = Cassidulina islandica Nørvang var. nor vangi Thalmann, 1952

Cassidulina? perumbonata Keyzer, 1953

Cassudulina cf. spinifera Cushman and Jarvis $=\mathrm{cf}$. Cassudulina spinifera Cushman and Jarvis, 1929

Ceratobulimina pacifica Cushman and Harris, 1927

Chilostomella oolina Schwager, 1878

Chilostomella ovoidea Reuss, 1850

Cibicides aknerianus (d'Orbigny) = Rotalia akneriana d'Orbigny, 1846

Cibicides lobatulus (Warker and Jacob) $=$ Nautilus lobatulus Walker and Jacob, 1798

Cibicides refulgens Montfort, 1808

Cibicides robertsonianus $($ Brady) $=$ Truncatulina robertsoniana Brady, 1881

Cibicides tenuimargo $($ Brady $)=$ Truncatulina tenuimargo Brady, 1884

Cibicides wuellerstorfi (Schwager) = Anomalina wuellerstorfi Schwager, 1866

Cibicidoides eocaenus $($ Gümbel) $=$ Rotalia eocaena Gümbel, 1868

Cibicidoides laurisae (Mallory) = Cibicides laurisae Mallory, 1959

Cibicidoides mediocris (Finlay) $=$ Cibicides mediocris Finlay, 1940

Cibicidoides mundulus (Brady, Parker and Jones) = Truncatulina mundula Brady, Parker and Jones, 1888

Cribrorbulina serpens $($ Seguenza $)=$ Robulina serpens Seguenza, 1880

Cyclogyra involvens (Reuss) = Operculina involvens Reuss, 1850

Cymbaloporetta bradyi $($ Cushman $)=$ Cymbalopora poeyi $($ d'Orbigny $)$ var bradyi Cushman, 1915

Cystammina pauciloculata $($ Brady $)=$ Trochammina pauciloculata Brady, 1879

Discorbinella bertheloti (d'Orbigny) = Rosalina bertheloti d'Orbigny, 1839

Discorbinella biconcavus (Jones and Parker) = Discorbina biconcava Jones and Parker in Carpenter, Parker and Jones, 1862

Discorbinella convexa (Takayanagi) = Planulina convexa Takayanagi, 1953

Discorbinella subbertheloti $($ Cushman $)=$ Discorbis subbertheloti Cushman, 1924

Discorbis mira Cushman, 1922

Ehrenbergina albatrossi Cushman, 1933

Ehrenbergina bicornis Brady, 1888

Ehrenbergina hystrix Brady, 1881

Ehrenbergina marwicki Finlay, 1939

Ehrenbergina pacifica Cushman, 1927

Ehrenbergina trigona Goës = Ehrenbergina serrata Reuss var. trigona Goës, 1896

Elphidium advena $($ Cushman $)=$ Polystomella advena Cushman, 1922

Elphidium cf. crispum (Linné) $=$ cf. Nautilus crispum Linné, 1758

Elphidium jenseni $($ Cushman $)=$ Polystomella jenseni Cushman, 1924

Elphidium poeyanum (d'Orbigny) = Polystomella poeyana d'Orbigny, 1839

Elphidium simplex Cushman, 1933

Eponides tumidulus (Brady) = Truncatulina tumidula Brady, 1884

Evolvocassidulina brevis $($ Aoki $)=$ Cassidulina brevis Aoki, 1968

Favocassidulina favus (Brady) = Pulvinulina favus Brady, 1877

Fijiella simplex (Cushman) = Trimosina simplex Cushman, 1929

Fissurina alveolata (Brady) = Lagena alveolata Brady, 1884

Fissurina annectens (Burrows and Holland) = Lagena annectens Burrows and Holland in Jones, 1895

Fissurina auriculata $($ Brady) = Lagena auriculata Brady, 1881

Fissurina auriculata duplicata (Sidebottom) = Lagena auriculata Brady var. duplicata Sidebottom, 1912

Fissurina clathrata (Brady) = Lagena clathrata Brady, 1884

Fissurina crebra (Matthes) = Lagena crebra Matthes, 1939

Fissurina denica $($ Madsen $)=$ Lagena denica Madsen, 1895

Fissurina fimbriata (Brady) = Lagena fimbriata Brady, 1881

Fissurina cf. formosa favosa (Brady) = cf. Lagena formosa Schwager var. favosa Brady, 1884

Fissurina kerguelenensis Parr, 1950

Fissurina lacunata (Burrows and Holland) = Lagena lacunata Burrows and Holland, 1895
Fissurina lucida $($ Williamson $)=$ Entosolenia marginata $($ Montagu $)$ var. lucida Williamson, 1848

Fissurina marginata $($ Montagu $)=$ Vermiculum marginatum Montagu, 1803

Fissurina orbignyana Seguenza, 1862

Fissurina palliolata (Earland) = Lagena palliolata Earland, 1934

Fissurina quenquelatera $($ Brady) $=$ Lagena quenquelatera Brady, 1881

Fissurina radiata Seguenza, 1862

Fissurina radiata striatula $($ Cushman $)=$ Lagena sublagenoides var. striatula Cushman, 1913

Fissurina aff. trigonomarginata (Parker and Jones) = aff. Lagena trigonomarginata Parker and Jones, 1865

Fursenkoina complanata $($ Egger) = Virgulina schreibersiana Czjzek var. complanata Egger, 1893

Gavelinopsis praegeri (Heron-Allen and Earland) = Discorbina praegeri Heron-Allen and Earland, 1913

Glandulina laevigata (d'Orbigny) = Nodosaria laevigata d'Orbigny, 1826

Globobulimina auriculata $($ Bailey) = Bulimina auriculata Bailey, 1851

Globobulimina pacifica Cushman, 1927

Globobulimina pupoides (d'Orbigny) = Bulimina pupoides d'Orbigny, 1846

Globocassidulina brocha (Poag) = Cassidulina brocha Poag, 1966

Globocassidulina cressa (d'Orbigny) = Cassidulina cressa d'Orbigny, 1839

Globocassidulina decorata $($ Sidebottom $)=$ Cassidulina decorat $a$ Sidebottom 1910

Globocassidulina elegans $($ Sidebottom $)=$ Cassidulina elegans Sidebottom, 1910

Globocassidulina gemma $($ Todd $)=$ Cassidulina gemma Todd in Cushman, Todd and Post, 1954

Globocassidulina moluccensis $($ Germeraad $)=$ Cassidulina moluccensis Germeraad, 1946

Globocassidulina mucronata Nomura, 1983

Globocassidulina neobrocha Nomura, 1983

Globocassidulina oblonga (Reuss) = Cassidulina oblonga Reuss, 1850

Globocassidulina oriangulata (Belford) = Cassidulina oriangulata Belford, 1966

Globocassidulina oribunda Belford, 1966

Globocassidulina ornata (Cushman) = Cassidulina subglobosa Brady var ornata Cushman, 1927

Globocassidulina paratortuosa $($ Kuwano $)=$ Cassidulina paratortuosa $\mathrm{Ku}$ wano, 1954

Globocassidulina parva (Asano and Nakamura) = Cassidulina subglobosa Brady parva Asano and Nakamura, 1937

Globocassidulina parviapertura Nomura, 1983

Globocassidulina patula $($ Cushman $)=$ Cassidulina patula Cushman, 1933

Globocassidulina subglobosa (Brady) = Cassidulina subglobosa Brady, 1881

Globocassidulina subtumida $($ Cushman $)=$ Cassidulina subtumida Cushman, 1933

Globulina flexa Cushman and Ozawa, 1930

Glomospira gordialis (Jones and Parker) = Ammodiscus gordialis Jones and Parker, 1880

Gyroidina altiformis R. E. and K. C. Stewart = Gyroidina soldanii var. altiformis R. E. and K. C. Stewart, 1930

Gyroidina cf. broeckhiana (Karrer) = cf. Rotalia broeckhiana Karrer, 1878

Gyroidina cushmani Boomgraad, 1949

Gyroidina neosoldanii Brotzen, 1936

Gyroidina orbicularis d'Orbigny, 1826

Gyroidina soldanii d'Orbigny, 1826

Gyroidinoides lamarckianus (d'Orbigny) = Rotalia lamarckiana d'Orbigny, 1839

Gyroidinoides nipponicus (Ishizaki) = Gyroidina nipponica Ishizaki, 1944

Hanzawaia mantaensis (Galloway and Molley) = Anomalina mantaensis Galloway and Molley, 1929

Hauerina bradyi Cushman, 1917

Heronallenia lingulata (Burrows and Holland) = Discorbina lingulata Burrows and Holland, 1896

Heterolepa haidingerii (d'Orbigny) = Rotalia haidingerii d'Orbigny, 1846

Hoeglundina elegans (d'Orbigny) = Rotalia elegans d'Orbigny, 1826

Hormosina globulifera Brady, 1879

Hyalina balthica (Schröter) = Nautilus balthicus Schröter, 1783

Islandiella norcrossi $($ Cushman $)=$ Cassidulina norcrossi Cushman, 1933

Lagena acuticosta Reuss, 1861

Lagena advena Cushman, 1923

Lagena elongata $($ Ehrenberg $)=$ Miliola elongata Ehrenberg, 1844

Lagena gracilis Williamson, 1848

Lagena gracillima $($ Seguenza $)=$ Amphorina gracillima Seguenza, 1862 
Lagena hispidula Cushman, 1858

Lagena laevis $($ Montagu $)=$ Vermiculum laevis Montagu, 1803

Lagena nebulosa Cushman = Lagena laevis (Montagu) var. nebulosa Cushman, 1923

Lagena paradoxa Sidebottom = Lagena foleolata Reuss var. paradoxa Sidebottom, 1912

Lagena parri Loeblich and Tappan, 1953

Lagena perlucida $($ Montagu $)=$ Vermiculum perlucidum Montagu, 1803

Lagena pliocenica Cushman and Gray, 1946

Lagena plumigera Brady, 1881

Lagena striata (d'Orbigny) = Oolina striata d'Orbigny, 1839

Lagena substriata Williamson, 1848

Lagena sulcata laevicostata Cushman and Gray = Lagena sulcata (Warker and Jacob) var. laevicostata Cushman and Gray, 1946

Lagena sulcata spicata Cushman and McCulloch = Lagena sulcata var. spicata Cushman and McCulloch, 1950

Lagena williamsoni $($ Alcock $)=$ Entosolenia williamsoni Alcock, 1865

Lamarkina scabra (Brady) = Pulvinulina oblonga (Williamson) var. scabra Brady, 1884

Laterostomella voluta Belford, 1966

Laticarina altocamerata $($ Helon-Allen and Earland $)=$ Truncatulina altocamerata Helon-Allen and Earland, 1922

Laticarina pauperata $($ Parker and Jones) $=$ Palvinulina repanda Fichtel and Moll var. menardii d'Orbigny subvar. pauperata Parker and Jones, 1865

Lernella seranensis $($ Germeraad $)=$ Cassidulina seranensis Germeraad, 1946

Marginulina glabra d'Orbigny, 1826

Marginulina subcrassa Schwager, 1866

Marginulina tenuis Bornemann, 1855

Marginulinopsis bradyi (Goës) = Cristellaria bradyi Goës, 1894

Marsipella cylindrica Brady, 1882

Melonis barleeanus (Williamson) = Nonionina barleeana Williamson, 1858

Melonis pacificus $($ Cushman) $=$ Nonionina umbilic ztula (Montagu) var. pacifica Cushman, 1924

Melonis parkerae $($ Uchio $)=$ Nonion parkerae Uchio, 1960

Melonis sphaeroides Voloshinova, 1958

Miliolinella circularis (Bornemann) = Triloculina circularis Bornemann, 1855

Miliolinella inflata LeRoy, 1964

Neoconorbina floridensis (Cushman) = Discorbis bertheloti (d'Orbigny) var. floridensis Cushman, 1931

Neoconorbina terquemi $($ Rzehak $)=$ Discorbina terquemi Rzehak, 1888

Nodosaria flintii Cushman, 1923

Nodosaria longiscata d'Orbigny, 1846

Nodosaria pyrula d'Orbigny, 1826

Nodosaria simplex Silvestri, 1872

Nonion depressulum (Walker and Jacob) $=$ Nautilus depressulum Walker and Jacob, 1798

Nonion planatum Cur'iman and Thomas, 1930

Nonionella japonica mexicana Cushman and $\mathrm{McCulloch}=$ Nonionella japon ica (Asano) var. mexicana Cushman and McCulloch, 1940

Nonionella miocenica Cushman, 1926

Nonionella miocenica stella Cushman and Moyer = Nonionella miocenica Cushman var. stella Cushman and Moyer, 1930

Nonionellina labradorica $($ Dawson $)=$ Nonionina labradorica Dawson, 1860

Nuttallides umbonifera $($ Cushman $)=$ Pulvinulinella umbonifera Cushman, 1933

Oolina apiopleura (Loeblich and Tappan) = Lagena apiopleura Loeblich and Tappan, 1953

Oolina globosa $($ Montagu $)=$ Vermiculum globosum Montagu, 1803

Oolina hexagona (Williamson) = Entosolenia sequamosa (Montagu) var hexagona Williamson, 1858

Oolina melo d'Orbigny, 1839

Operculina ammonoides (Gronovius) = Nautilus ammonoides Gronovius, 1781

Oridorsalis pauciapertura Belford, 1966

Oridorsalis tener (Brady) $=$ Truncatulina tenera Brady, 1884

Oridorsalis umbonatus (Reuss) = Rotalia umbonata Reuss, 1851

Orthomorphina challengeriana (Thalmann) = Nodogeneria challengeriana Thalmann, 1937

Osangularia culter (Parker and Jones) $=$ Planorbulina culter Parker and Jones, 1865

Ozawaia tongaensis Cushman, 1931

Paracassidulina miuraensis (Higuchi) = Cassidulina miuraensis Higuchi, 1956
Paracassidulina neocarinata $($ Thalmann $)=$ Cassidulina neocarianta Thalmann, 1950

Paracassidulina nipponensis $($ Eade $)=$ Globocassidulina nipponensis Eade 1967

Paracassidulina quasicarinata Nomura, 1983

Paracassidulina sulcata (Belford) = Cassidulina sulcata Belford, 1966

Parafissurina arctica Green, 1959

Parafissurina lateralis Cushman, 1913

Parafissurina pseudomarginata (Bucher)=Lagena pseudomarginata Bucher, 1940

Parafissurina subcarinata Parr, 1950

Parafissurina uncifera (Buckner) = Lagena uncifera Buckner, 1940

Parafrondicularia helenae Chapman, 1940

Parrelloides bradyi (Trauth) $=$ Truncatulina bradyi Trauth, 1918

Parrelloides cf. soendaensis (LeRoy) $=\mathrm{cf}$. Cibicides soendaensis LeRoy, 1941

Patellinella carinata Collins, 1958

Patellinella jugosa (Brady) = Textularia jugosa Brady, 1884

Peneropsis pertusus (Forskal) $=$ Nautilus pertusus Forskal, 1775

Pileolina patelliformis $($ Brady $)=$ Discorbina patelliformis Brady, 1884

Pileolina tabernacularis (Brady) $=$ Discorbina tabernacularis Brady, 1884

Planorbulina mediterranensis d'Orbigny, 1826

Planulina ariminensis d'Orbigny, 1826

Pleurostomella alternans Schwager, 1866

Pleurostomella brevis Schwager, 1866

Pleurostomella rapa Gümbel, 1868

Pleurostomella recens Dervieux $=$ Pleurostomella rapa Gümbel var. recens Dervieux, 1899

Pleurostomella subnodosa (Reuss) = Nodosaria subnodos Reuss, 1845

Pseudononion auricula (Heron-Allen and Earland) $=$ Nonionella auricula Heron-Allen and Earland, 1930

Pseudononion grateloupi (d'Orbigny) = Nonionina grateloupi d'Orbigny, 1826

Pseudoparrella exigua $($ Brady) $=$ Pulvinulina exigua Brady, 1884

Pseudopolymorphina ligua $($ Roemer $)=$ Polymorphina ligua Roemer, 1838

Pseudorotalia gaimardii (d'Orbigny) = Rotalia gaimardii d'Orbigny, 1826

Pullenia bulloides (d'Orbigny) $=$ Nonionina bulloides d'Orbigny, 1846

Pullenia quinqueloba (Reuss) = Nonionina quinqueloba Reuss, 1851

Pullenia salisburyi R.E. and R. C. Stewart, 1930

Pyrgo denticulata $($ Brady $)=$ Biloculina ringens Lamarck var. denticulata Brady, 1884

Pyrgo depressa (d'Orbigny) = Biloculina depressa d'Orbigny, 1826

Pyrgo lucernula $($ Schwager $)=$ Biloculina lucernula Schwager, 1866

Pyrgo murrhina (Schwager) = Bioculina murrhina Schwager, 1866

Quadratobuliminella pyramidalis de Klasz, 1953

Quadrimorphina laevigata (Phleger and Parker) = Valvulineria laevigata Phleger and Parker, 1951

Quinqueloculina akneriana d'Orbigny, 1846

Quinqueloculina bicostata d'Orbigny, 1839

Quinqueloculina costata d'Orbigny, 1826

Quinqueloculina lamarkiana d'Orbigny, 1839

Quinqueloculina seminula $($ Linné) $=$ Serpula seminulum Linné, 1767

Quinqueloculina vulgaris d'Orbigny, 1826

Ramulina globulifera Brady, 1879

Rectobolivina columellaris $($ Brady $)=$ Sagrina columellaris Brady, 1881

Rectobolivina dimorpha pacifica Cushman $=$ Siphogeneria dimorpha (Parker and Jones) var. pacifica Cushman, 1926

Rectobolivina indica (LeRoy) = Siphogeneria indica LeRoy, 1941

Rectobolivina limbata (Brady) = Bolivina limbata Brady, 1881

Rectobolivina limbata costulata (Cushman) = Bolivina limbata Brady var. costulata Cushman, 1922

Rectobolivina raphana $($ Parker and Jones) = Uvigerina $($ Sagrina $)$ raphanus Parker and Jones, 1865

Rectuvigerina striata $($ Schwager $)=$ Dimorphina striata Schwager, 1866

Rectuvigerina tasmana Boersma, 1984

Reussella aculeata Cushman, 1945

Rhabdammina abyssorum M. Sars, 1868

Rhizammina algaeformis Brady, 1879

Robertina oceanica Cushman and Parker, 1947

Robulus gibbus (d'Orbigny) = Cristellaria gibba d'Orbigny, 1826

Robulus limbosus (Reuss) = Robulina limbosus Reuss, 1863

Robulus orbicularis d'Orbigny, 1826

Robulus reniformis (d'Orbigny) = Cristellaria reniformis d'Orbigny, 1846

Rosalina floridana $($ Cushman $)=$ Discorbis floridana Cushman, 1922 
Rosalina globularis d'Orbigny, 1826

Rosalina vilardeboana d'Orbigny, 1839

'Rotalia' murrayi Heron-Allen and Earland = Rotalia murrayi Heron-Allen and Earland, 1915

Rutherfordoides cornuta $($ Cushman $)=$ Virgulina cornuta Cushman, 1913

Rutherfordoides tenuis (Phleger and Parker) $=$ Cassidulinoides tenuis Phleger and Parker, 1951

Saracenaria italica Defrance, in Blaineville, 1824

Saracenaria latifrons $($ Brady) $=$ Cristellaria latifrons Brady, 1884

Sigmavirgulina tortuosa (Brady) $=$ Bolivina tortuos Brady, 1881

Sigmoilopsis schlumbergeri $($ Silvestri $)=$ Sigmoilina schlumbergeri Silvestri, 1904

Siphotextularia concava (Karrer) = Plecanium concavum Karrer, 1868

Siphotextularia saulcyana (d'Orbigny) = Textularia saulcyana d'Orbigny, 1839

Sorites marginalis (Lamarck) = Orbulites marginalis Lamarck, 1816

Sphaeroidina bulloides d'Orbigny, 1826

Sphaeroidina compacta Cushman and Todd, 1949

Spiroloculina communis Cushman and Todd, 1944

Stanforthia exilis (Brady) = Bulimina elegans d'Orbigny var. exilis Brady, 1884

Stilostomella abyssorum $($ Brady) $=$ Nodosaria abyssorum Brady, 1881

Stilostomella consobrina (d'Orbigny) $=$ Dentalina consobrina d'Orbigny, 1846

Stilostomella $\mathrm{cf}$. fistuca (Schwager) $=\mathrm{cf}$. Nodosaria fistuca Schwager, 1866

Stilostomella lepidula (Schwager) = Nodosaria lepidula Schwager, 1866

Tappanina selmensis $($ Cushman) = Bolivinita selmensis Cushman, 1948

Thalmannammina parkerae $($ Uchio) $=$ Recurvoidella parkerae Uchio, 1960

Tosaia hanzawai Takayanagi, 1953

Trifarina angulosa (Williamson) = Uvigerina angulosa Williamson, 1885

Trifarina bradyi Cushman, 1923

Trifarina occidentalis $($ Cushman $)=$ Uvigerina occidentalis Cushman, 1923

Triloculina tricarinata d'Orbigny, 1826

Triloculina trigonula $($ Lamarck $)=$ Miliolites trigonula Lamarck, 1804

Turrilina brevispira ten Dam, 1944

Trochammina conglobata Brady, 1884

Trochammina discorbis Earland, 1934

Trochammina globigeriniformis (Parker and Jones) = Lituola nautiloidea var globigeriniformis Parker and Jones, 1865

Trochammina pacifica Cushman, 1925

Tubulogenerina zanzibarica $($ Cushman $)=$ Brizalina zanzibarica Cushman, 1936

Uvigerina aculeata d'Orbigny, 1846

Uvigerina ampullacea Brady = Uvigerina asperula Czjzek var. ampullacea Brady, 1884

Uvigerina hispida Schwager, 1866

Uvigerina hispidocostata Cushman and Todd, 1945

Uvigerina interrupta Brady, 1879

Uvigerina peregrina Cushman, 1923

Uvigerina porrecta Brady, 1879

Uvigerina proboscidea Schwager, 1866

Uvigerina $\mathrm{cf}$. tasmana Boersma $=\mathrm{cf}$. Uvigerina tasmana Boersma, 1984

Vaginulinopsis tasmanica Parr, 1950

Valvulineria gunjii Akimoto, 1990

\section{ACKNOWLEDGMENTS}

The author is deeply indebted to the following persons: Professor Motoyoshi Oda of Kumamoto University for discussion of paleontological problems and critical reading of the manuscript; Professor Yokichi Takayanagi of Tohoku University, Professor James C. Ingle of Stanford University, Co-Chief Scientists of ODP Leg 134 Dr. H. Gary Greene and Dr. Jean-Yves Collot, and Dr. Laura B. Stokking, ODP Leg 134 Staff Scientist, for critical reading of the manuscript; $\mathrm{Mr}$. Shohei Ohtomo of the Tohoku University for photographic assistance; Miss Mariko Kobayashi and Miss Ayumi Takemoto of Kumamoto University for their assistance with computer analysis.

The author processed foraminiferal samples in the Department of Geology, Faculty of Science, Kumamoto University. SEM micrographs of foraminifers were obtained using the Scanning Electron Microscope at the Institute of Geology and Paleontology, Faculty of Science, Tohoku University.
This study was supported by a Grant-in-Aid for Encouragement of Young Scientists (K. Akimoto, Project Nos. 03740410 and 04740447) from the Ministry of Education, Science and Culture, Japan.

\section{REFERENCES}

Akimoto, K., 1990. Distribution of Recent benthic foraminiferal faunas in the Pacific off Southwest Japan and around Hachijojima Island. Sci. Rep. Tohoku Univ., Ser. 2, 60:139-223.

1991. Paleoenvironmental studies of the Nishiyatsushiro and Shizukawa Groups, South Fossa-Magna region. Sci. Rep. Tohoku Univ., Ser. 2, 61:1-102.

Burke, S.C., 1981. Recent benthic foraminifera of the Ontong Java Plateau. $J$. Foraminiferal Res., 11:1-19.

Carney, J.N., 1986. Geology of Maewo. Region. Rep.-Vanuatu Dep. Geol., Mines and Rural Water Supplies.

Chase, C.G., 1971. Tectonic history of the Fiji plateau. Geol. Soc. Am. Bull., 82:3087-3110.

Collot, J.-Y., Greene, H.G., Stokking, L.B., et al., 1992a. Site 827. Proc. ODP Init. Repts., 134: College Station, TX (Ocean Drilling Program), 95-123. 1992b. Site 828. Proc. ODP Init. Repts., 134: College Station, TX (Ocean Drilling Program), 139-165.

, 1992c. Site 829. Proc. ODP. Init. Repts., 134: College Station, TX (Ocean Drilling Program), 179-229.

, 1992d. Site 832. Proc. ODP. Init. Repts., 134: College Station, TX (Ocean Drilling Program), 387-435.

Cushman, J.A., 1921. Contributions to the biology of the Philippine archipelago and adjacent region. Bull-U.S. Nat. Mus., 100:1-488 , 1932. The foraminifera of the tropical Pacific collections of the "Albatross," 1899-1900. Pt.1-Astrorhizidae to Trochamminidae. BullU.S. Nat. Mus., 161:1-84.

1933. The foraminifera of the tropical Pacific collections of the "Albatross," 1899-1900. Pt. 2-Lagenidae and Alveolinellidae. Bull.U.S. Nat. Mus., 161:1-79.

, 1942. The foraminifera of the tropical Pacific collections of the "Albatross," 1899-1900. Pt. 3-Hetreohelicidae and Buliminidae. Bull.U.S. Nat. Mus., 161:1-67.

Cushman, J.A., Todd, R., and Post, R.J., 1954. Recent Foraminifera of the Marshall islands, Bikini and nearby atolls. Part 2: Oceanography (Biologic). Geol. Surv. Prof. Pap. U.S., 260-H:319-384.

Davis, J.C., 1973. Statistics and Data Analysis in Geology: New York (Wiley),

Hasegawa, S., 1984. Note on the taxonomy and paleoecology of Melonis pompilioides and its allied taxa from Japan. In Oertli, H.J. (Ed.), Benthos '83, 2nd Int. Symp. on Benthic Foraminifera (Pau, 1983), 299-304.

Hermelin, J.O.R., 1989. Pliocene benthic foraminifera from the Ontong-Java plateau (Western Equatorial Pacific Ocean): faunal response to changing paleoenvironment. Spec. Publ. Cushman Found. Foraminiferal Res., 26:1-143.

Kennett, J.P., 1982. Marine Geology: Englewood Cliffs, NJ (Prentice Hall).

Kurihara, K., and Kennett, J.P., 1986. Neogene benthic foraminifers: distribution in depth traverse, southwest Pacific. In Kennett, J.P., von der Borch, C.C., et al., Init. Repts. DSDP, 90: Washington (U.S. Govt. Printing Office), 1037-1077.

Luyendyk, B.P., Bryan, W.B., and Jezek, P.A., 1974. Shallow structure of the New Hebrides island arc. Geol. Soc. Am. Bull., 85:1287-1300.

Macfarlane, A., Carney, J.N., Crawford, A.J., and Greene, H.G., 1988. Vanuatu-a review of the onshore geology. In Greene, H.G., and Wong, F.L. (Eds.), Geology and Offshore Resources of Pacific Island Arcs-Vanuatu Region. Circum-Pac. Counc. Energy and Miner. Resour., Earth Sci. Ser., $8: 45-91$.

Maiya, S., and Inoue, Y., 1973. On the effective treatment of rocks for microfossil analysis. Fossils (Paleontol. Soc. Jpn.), 25-26:87-96. (in Japanese)

Mallick, D.I.J. and Greenbaum, D., 1977. Geology of southern Santo. New Hebrides Geol. Surv., 1-84.

Nienstedt, J.C., and Amold, A.J., 1988. The distribution of benthic foraminifera on seamounts near the East Pacific Rise. J. Foraminiferal Res., $18: 237-249$.

\footnotetext{
- Abbreviations for names of organizations and publications in ODP reference lists follow the style given in Chemical Abstracts Service Source Index (published by American Chemical Society).
} 
Nishi, H., 1992. The depth distribution of living benthic foraminifera within marine sediments of Suruga and Sagami Bays, off the southern coast of Japan. In Takayanagi, Y., and Saito, T. (Eds.), Studies in Benthic Foraminifera: Tokyo (Tokai Univ. Press), 109-116.

Oki, K., 1985. Preliminary report on foraminifera from the habitat of Nautilus off the southeast coast of Viti Levu, Fiji. In Hayasaka, S. (Ed.), Marine Ecological Studies on the Habitat of Nautilus pompilius in the Environs of Viti Levu, Fiji. Kagoshima Univ. Res. Cent. South Pacific, Occas. Pap., 4:84-92.

1988. Notes on the Assemblages of benthonic foraminifera from the habitat of Nautilus in Fiji. Kagoshima Univ. Res. Cent. South Pacific, Occas. Pap., 15:74-84.

Pflum, C.E., and Frerichs, W.E., 1976. Gulf of Mexico deep-water foraminifers. Spec. Publ. Cushman Found. Foraminiferal Res., 14:1-122.

Robinson, G.P., 1969. The geology of north Santo. Rep.-New Hebrides Geol. Surv., 1-77.

Todd, R., 1965. The foraminifera of the tropical Pacific collections of the Albatross, 1899-1900. Part 4: Rotaliform families and planktonic families. Bull.-U.S. Nat. Mus., 161:1-139. van Morkhoven, F.P.C.M., Berggren, W.A., and Edwards, A.S., 1986. Cenozoic cosmopolitan deep-water benthic foraminifera. Bull. Cent. Rech. Explor-Prod. Elf-Aquitaine, Mem. 11.

Woodruff, F., 1985. Changes in Miocene deep-sea benthic foraminiferal distribution in the Pacific Ocean: relationship to paleoceanography. In Kennett, J.P. (Ed.), The Miocene Ocean: Paleoceanography and Biogeography. Mem.-Geol. Soc. Am., 163:131-175.

Yasuda, H., Takayanagi, Y., and Hasegawa, S., 1985. On the sodium tetraphenylborate method for hard-rock maceration. Fossils (Paleontol. Soc. Jpn.), 30:17-27. (in Japanese)

Date of initial receipt: 10 June 1992

Date of acceptance: 30 July 1993

Ms 134SR-011 

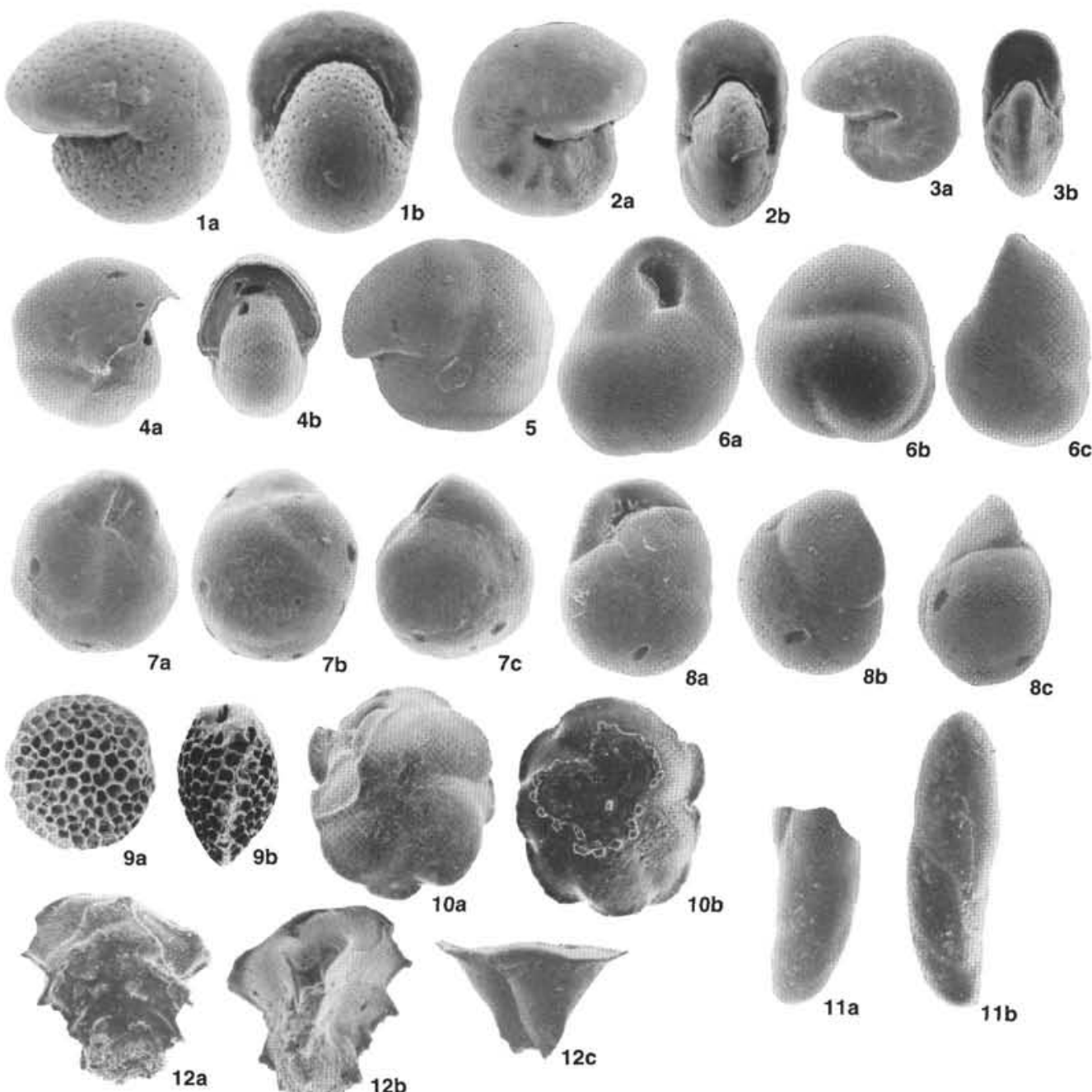

Plate 1. 1. Melonis sphaeroides Voloshinova, Sample 134-832A-1H-CC, $\times 75$, (a) side view, (b) apertural view. 2. Melonis barleeanus (Williamson), Sample 134-832A-4H-CC, $\times 50$, (a) side view, (b) apertural view. 3. Melonis parkerae (Uchio), Sample 134-827A-11H-CC, $\times 50$, (a) side view, (b) apertural view. 4. Pullenia quinqueloba (Reuss), Sample 134-832A-6H-CC, $\times 100$, (a) side view, (b) apertural view. 5. Pullenia bulloides (d'Orbigny), Sample $134-832 \mathrm{~A}-12 \mathrm{H}-\mathrm{CC}, \times 100.6$. Globocassidulina moluccensis (Germeraad), Sample 134-832A-4H-CC, $\times 75$, (a) apertural view, (b) and (c) side view. 7. Globocassidulina ornata (Cushman), Sample 134-827A-15X-CC, $\times 75$, (a) apertural view, (b) and (c) side view. 8. Globocassidulina cressa (d’Orbigny), Sample 134-832A-8H-CC, $\times 150$, (a) apertural view, (b) and (c) side view. 9. Favocassidulina favus (Brady), Sample 134-832B-8R-CC, $\times 50$, (a) side view, (b) apertural view. 10. Cassidulina carinata Silvestri, Sample 134-827A-11H-CC, $\times 100$, (a) and (b) side view. 11. Rutherfordoides cornuta (Cushman), Sample 134-832A-2H-CC, $\times 75$, (a) and (b) side view. 12. Ehrenbergina pacifica Cushman, Sample 134-832B-32R-CC, $\times 75$, (a) and (b) side view, (c) apertural view. 


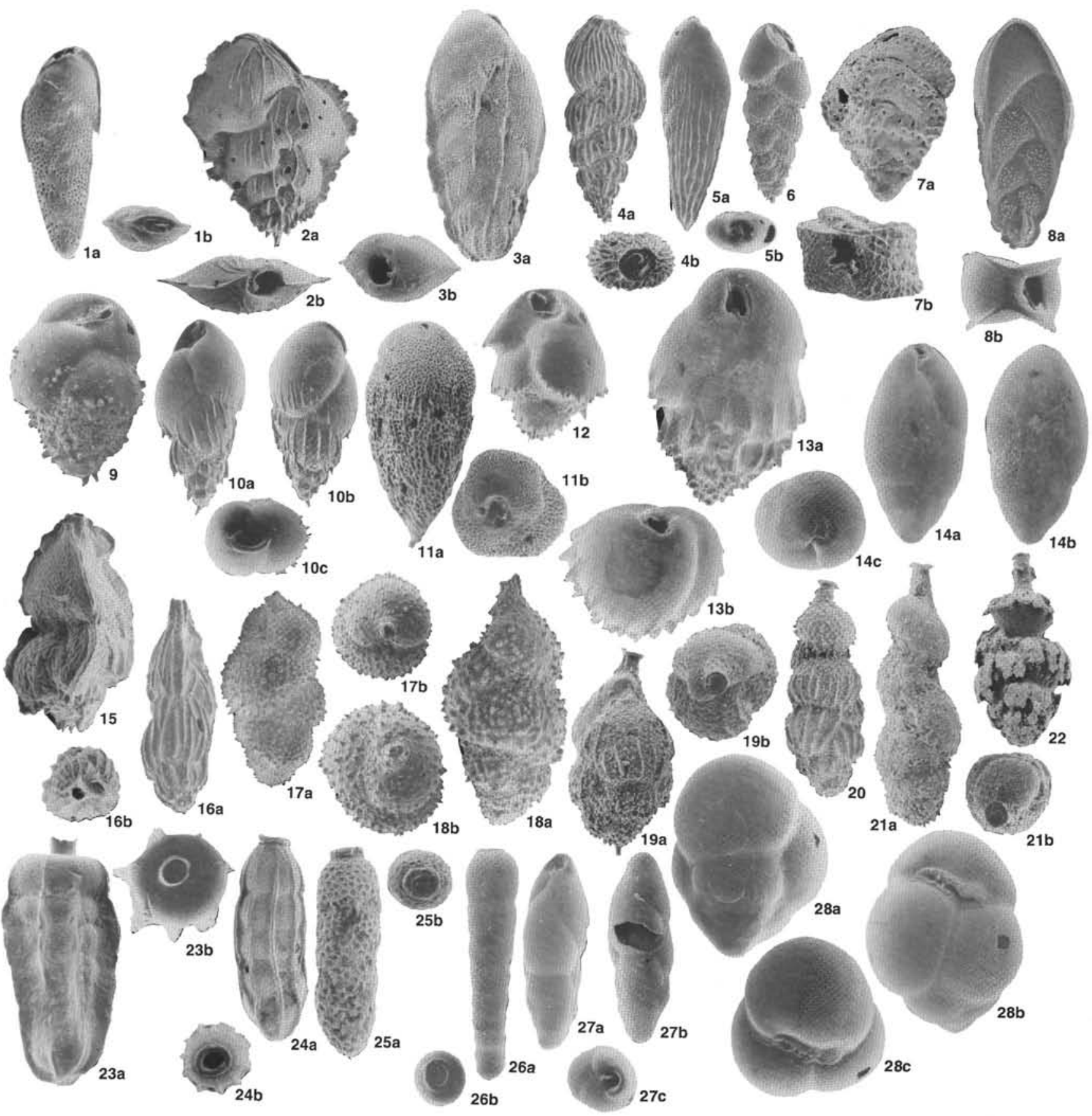

Plate 2. 1. Brizalina alata (Seguenza), Sample 134-827A-8H-CC, $\times 100$, (a) side view, (b) apertural view. 2. Brizalina hantkeniana (Brady), Sample 134-832A$8 \mathrm{H}-\mathrm{CC}, \times 100$, (a) side view, (b) apertural view. 3. Brizalina sp., Sample $832 \mathrm{~A}-6 \mathrm{H}-\mathrm{CC}, \times 150$, (a) side view, (b) apertural view. 4. Brizalina kerreriana (Brady), Sample 134-832A-8H-CC, $\times 100$, (a) side view, (b) apertural view. 5. Brizalina vescistriata Belford, Sample 134-832A-6H-CC, $\times 100$, (a) side view, (b) apertural view. 6. Bolivina subspinescens Cushman, Sample 134-832A-8H-CC, $\times 100,7$. Abditodentrix asketocomptella Patterson, Sample 134-832A-2H-CC, $\times 150$, (a) side view, (b) apertural view. 8. Bolivinita quadrilatera (Schwager), Sample 134-832A-8H-CC, $\times 100$, (a) side view, (b) apertural view. 9. Bulimina aculeata d'Orbigny, Sample 134-832A-11H-CC, $\times 150$. 10. Bulimina ampliaperture Belford, Sample 134-827A-8H-CC, $\times 150$, (a) and (b) side view, (c) apertural view. 11. Bulimina glomachallengeri Tjalsma and Lohmann, Sample 134-828A-10H-CC, $\times 75$, (a) side view, (b) apertural view. 12. Bulimina marginata d'Orbigny, Sample 134-827A-7H-CC, $\times 150$. 13. Bulimina striata d'Orbigny, Sample 134-832A-2H-CC, $\times 75$, (a) side view, (b) apertural view. 14. Globobulimina pupoides (d'Orbigny), Sample 134-827A-5H-CC, $\times 50$, (a) and (b) side view, (c) apertural view. 15. Trifariana angulosa (Williamson), Sample 134-832A-2H-CC, $\times 75$. 16. Trifarina occidentalis (Cushman), Sample 134-827A-7H-CC, $\times 150$, (a) side view, (b) apertural view. 17. Uvigerina hispida Schwager, Sample 134-832A-10H-CC, $\times 75$, (a) side view, (b) apertural view. 18. Uvigerina hispidocostata Cushman and Todd, Sample 134-832A-11H-CC, $\times 100$, (a) side view, (b) apertural view. 19. Uvugerina hispidocostata Cushman and Todd, Sample 134-832A-8H-CC, $\times 150$, (a) side view, (b) apertural view. 20. Uvigerina hispidocostata Cushman and Todd, Sample 134-827A-5H-CC, $\times 50$. 21. Uvigerina proboscidea Schwager, Sample 134-832B-3R-CC, $\times 100$, (a) side view, (b) apertural view. 22. Uvigerina porrecta Brady, Sample 134-828B-1R-CC, $\times 100$. 23. Rectobolivina raphana (Parker and Jones), Sample 134-832A-6H-CC, $\times 75$, (a) side view, (b) apertural view. 24. Rectobolivina cf. raphana (Parker and Jones), Sample 134-832A-12H-CC, $\times 75$, (a) side view, (b) apertural view. 25. Rectobolivina dimorpha (Parker and Jones), Sample 134-832A-2H-CC, $\times 100$, (a) side view, (b) apertural view. 26. Rectobolivina columellaris (Brady), Sample 134-832A-12H-CC, $\times 100$, (a) side view, (b) apertural view. 27. Stanforthia exilis (Brady), Sample 134-827A-7H-CC, $\times 100$, (a) and (b) side view, (c) apertural view. 28. Tosaia hanzawai (Takayanagi), Sample 134-832A-7H-CC, $\times 75$, (a) and (b) side view, (c) apertural view. 


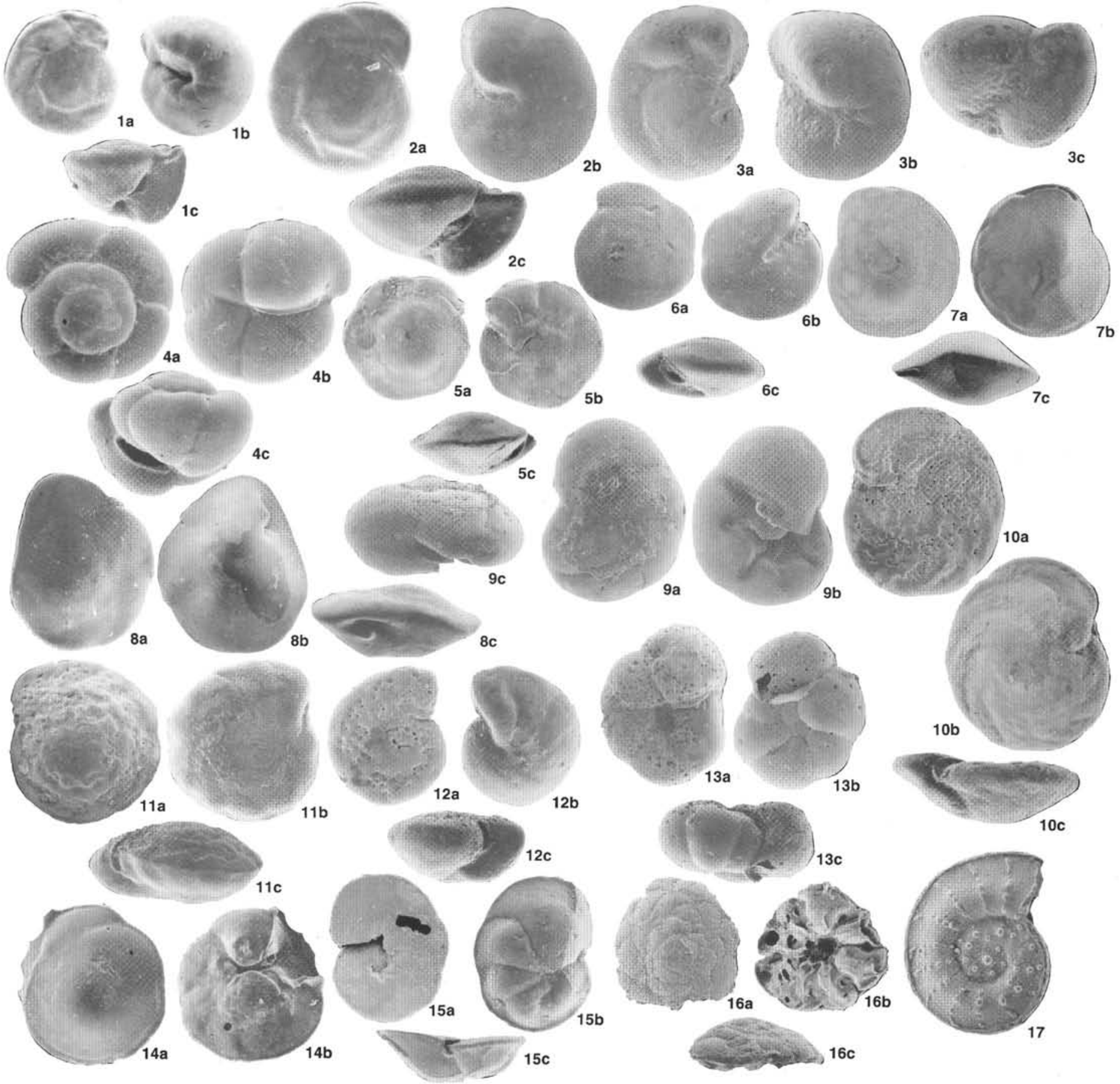

Plate 3. 1. Gyroidina altiformis R.E. and K.C. Stewart, Sample 134-832A-5H-CC, $\times 100$, (a) spiral side, (b) umbilical side, (c) lateral view. 2. Gyroidina orbicularis d'Orbigny, Sample 134-827B-4R-CC, $\times 75$, (a) spiral side, (b) umbilical side, (c) lateral view. 3. Gyroidina soldanii d'Orbigny, Sample 134-832B-32R-CC, $\times 50$, (a) spiral side, (b) umbilical side, (c) lateral view, 4. Gyroidinoides nipponicus (Ishizaki), Sample 134-832A-8H-CC, $\times 150$, (a) spiral side, (b) umbilical side, (c) lateral view. 5. Oridorsalis umbonatus (Reuss), Sample 134-832A-1H-CC, $\times 35$, (a) spiral side, (b) umbilical side, (c) lateral view. 6. Oridorsalis tener (Brady), Sample 134-832A-1H-CC, $\times 75$, (a) spiral side, (b) umbilical side, (c) lateral view. 7. Hoeglundina elegans (d'Orbigny), Sample 134-832A-1H-CC, $\times 35$, (a) spiral side, (b) umbilical side, (c) lateral view. 8. Pseudoparrella exigua (Brady), Sample 134-828A-2H-CC, $\times 100$, (a) spiral side, (b) umbilical side, (c) lateral view. 9. Varvulineria gunjii Akimoto, Sample 134-827A-5H-CC, $\times 100$, (a) spiral side, (b) umbilical side, (c) lateral view. 10. Cibicides wuellerstorfi (Schwager), Sample 134-832A-1H-CC, $\times 50$, (a) spiral side, (b) umbilical side, (c) lateral view. 11. Cibicidoides mundulus (Brady, Parker and Jones), Sample 134-832B-3R-CC, $\times 50$, (a) spiral side, (b) umbilical side, (c) lateral view. 12. Cibicidoides mediocris (Finlay), Sample 134-832A-4H-CC, $\times 75$, (a) spiral side, (b) umbilical side, (c) lateral view. 13. Anomalinoides glablosa (Chapman and Parr), Sample 134-832A-2H-CC, $\times 50$, (a) spiral side, (b) umbilical side, (c) lateral view. 14. Gavelinopsis praegeri (Heron-Allen and Earland), Sample 134-832A-7H-CC, $\times 100$, (a) spiral side, (b) umbilical side. 15. Discorbinella convexa (Takayanagi), Sample 134-832A-6H-CC, $\times 100$, (a) spiral side, (b) umbilical side, (c) lateral view. 16. Cymbaloporetta bradyi (Cushman), Sample 134-832A-2H-CC, $\times 50$, (a) spiral side, (b) umbilical side, (c) lateral view. 17. Operculina ammonoides (Gronovius), Sample 134-832A-5H-CC, $\times 22.5$. 


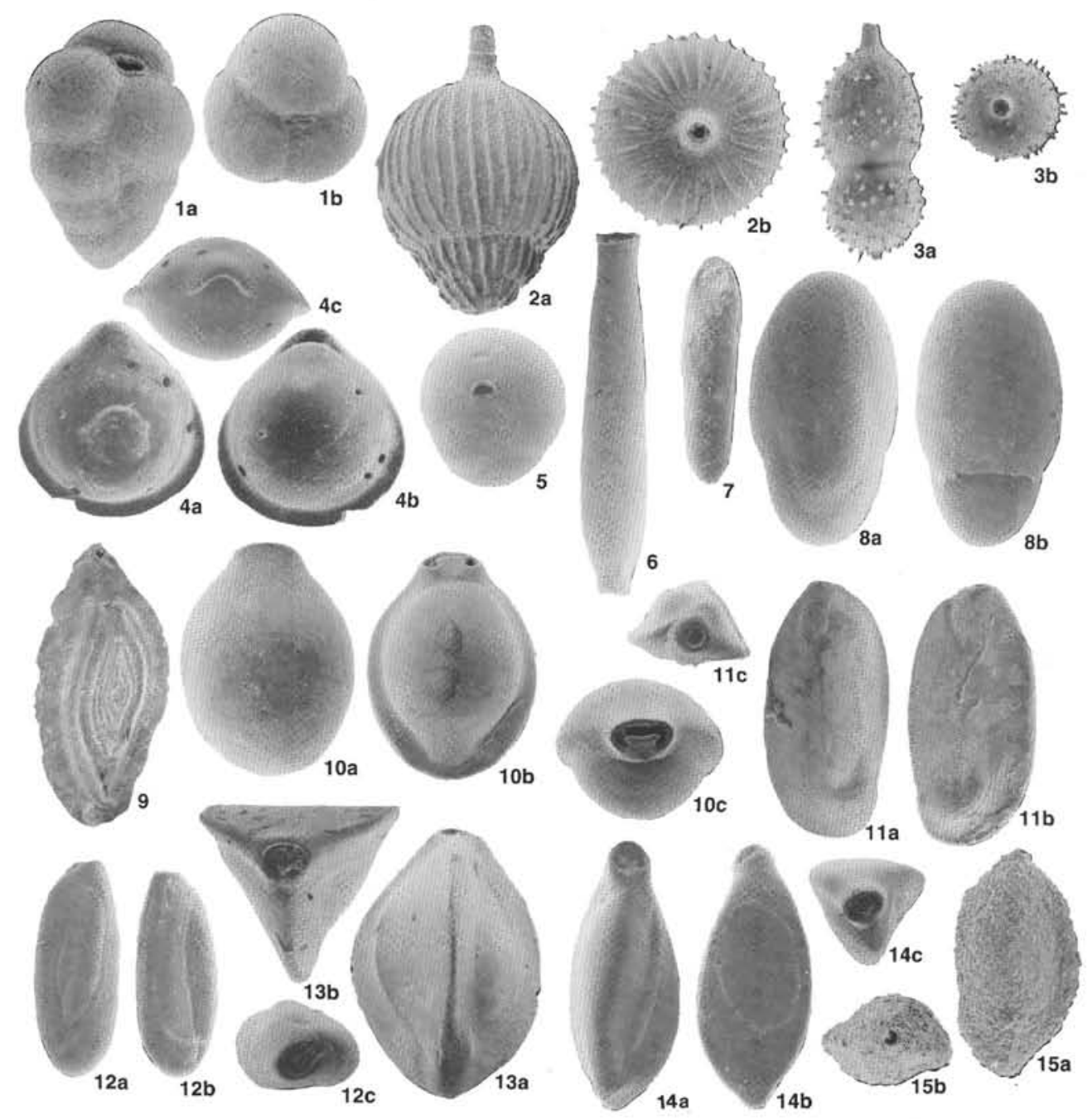

Plate 4. 1. Eggerella bradyi (Cushman), Sample 134-832A-1H-CC, $\times 50$, (a) side view, (b) apertural view. 2. Amphicoryna scaralis (Batsch), Sample 134-832A-2H-CC, $\times 75$, (a) side view, (b) apertural view. 3. Amphicoryna hirsuta (d'Orbigny), Sample 134-832A-2H-CC, $\times 100$, (a) side view, (b) apertural view. 4. Parafissurina pseudomarginata (Buchner), Sample 134-832B-8R$\mathrm{CC}, \times 75$, (a) and (b) side view, (c) apertural view. 5. Sphaeroidina compacta Cushman and Todd, Sample 134-832A-2H-CC, $\times 50$. 6. Nodosaria longiscata d'Orbigny, Sample $134-832 \mathrm{~B}-66 \mathrm{R}-\mathrm{CC}, \times 50.7$. Pleurostomella alternans Schwager, Sample 134-832B-63R-CC, $\times 50$. 8. Chilostomella oolina Schwager, Sample 134-832A-4H-CC, $\times 50$, (a) and (b) side view. 9. Spirophthalmidium actimargo (Brady), Sample 134-832A-1H-CC, $\times 35$. 10. Pyrgo fornasinii Chapman and Parr, Sample 134-832A$1 \mathrm{H}-\mathrm{CC}, \times 50$, (a) and (b) spiral side, (c) apertural view. 11. Quinqueloculina lamarckiana d'Orbigny, Sample 134-832A-1H-CC, $\times 50$, (a) and (b) spiral side, (c) apertural view. 12. Quinqueloculina seminula (Linné), Sample 134-832A-6H-CC, $\times 150$, (a) and (b) spiral side, (c) apertural view. 13. Triloculina tricarinata d'Orbigny, Sample 134-832B-29R-CC, $\times 50$, (a) spiral side, (b) apertural view, 14. Triloculina trigonula (Lamarck), Sample 134-832A-5H-CC, $\times 75$, (a) and (b) spiral side, (c) apertural view. 15. Sigmoilopsis schlumbergeri (Silvestri), Sample 134-827A-5H-CC $\times 50$, (a) spiral side, (b) apertural view. 